\title{
Climate change and cities: problem structuring methods and critical perspectives on low-carbon districts
}

\author{
Rachel Freeman ${ }^{\mathrm{a}}$, Mike Yearworth ${ }^{\mathrm{b}}$ \\ ${ }^{a}$ University of Manchester, Tyndall Centre for Climate Change Research, School of Mechanical, Aerospace and Civil \\ Engineering, United Kingdom \\ ${ }^{\mathrm{b}}$ University of Exeter, Business School, United Kingdom
}

$24 / 11 / / 2016$

\begin{abstract}
Cities around the world have set climate change mitigation targets, yet actions to implement these targets have so far proved inadequate. Better methodology is needed to support this impetus for action. Problem structuring methods (PSMs) enable improvements to be made in wicked problem situations; they appear to have potential to improve climate change mitigation actions but they are difficult to carry out in highly pluralist problem contexts. A case study (STEEP) that applied a PSM to support lowcarbon urban energy master planning in three cities is presented. The STEEP methodology was effective in reducing the wickedness of the problem but issues of a lack of clarity on problem ownership and lack of interessement were seen. A reflective boundary critique study found that there was a mismatch between power and interest amongst key stakeholders towards the low-carbon vision. Three key issues identified in the case study were discussed through the lens of critical systems thinking: (i) the need for new competencies, (ii) dealing with wickedness, and (iii) behavioural complexity and discordant reference systems. The paper suggests how these issues might be improved through the application of non-PSM theories which can support the use of PSMs in improving city-level climate change mitigation.
\end{abstract}

Key Words: Problem structuring methods; problematisation; Boundary Critique; climate change mitigation; critical systems thinking

\section{Introduction}

Recent decades have seen slow and insufficient progress on climate change mitigation - the reduction of human-caused greenhouse gas emissions to below a "safe" level, as recommended by climate science (Edenhofer et al. 2014). Climate change mitigation has been described as a "wicked" problem (Rittel \& Webber 1973) by some ((Australian Public Service Commission 2007), (Bailey et al. 2011)), indicating its systemic nature and the high levels of difficulty in enacting solutions. This difficulty is exemplified by an increase in the global average carbon intensity of energy supply between 2000 and 2007, despite worldwide investment in low-carbon generation technologies (Raupach et al. 2007). 
There is much potential for cities to play an active role in climate change mitigation. A $40 \%$ reduction in carbon emissions from UK cities could be possible by 2020 just from investing in cost-effective lowcarbon technologies (Sullivan et al. 2013). City governments often control some of the key factors related to carbon emissions such as land use planning, building regulations, public transport, and waste management (Kousky \& Schneider 2003). Across the world, cities are joining together to support each other in the goal of transitioning to a low-carbon future (for example, the C40 Cities Climate Leadership Group (www.c40.org) and Local Governments for Sustainability (www.iclei.org)). In reality, however, low-carbon cities are difficult to achieve. A study of eight new-build eco-cities found that the idea of building smart, sustainable cities is still relatively new and unproven, with projects being 'unprecedented in kind, if not in scale' (Alusi et al. 2011), and that (i) there is a lack of best practices and established performance standards in sustainable urbanisation; (ii) business models commonly used in Public-Private Partnerships may not work well for eco-cities; and (iii) getting developers and endusers to abide by standards for sustainability is difficult. Once an eco-city is operational, choices made by residents on housing and transportation can significantly impact the per-capita footprint of a city (Rees 1997). Flynn et al. (2016) provide some real-world evidence from an established eco-city. Their study found that whilst some parts of the residents' lifestyles are environmentally friendly, those parts concerned with comfort and convenience are generally not - for example, in increased use of cars for travel and routine use of air conditioning. Furthermore, due to the aspirations of the residents, resource use seems likely to rise in future. Finally, much of the infrastructure being built in the eco-city may end up being not used or used in inappropriate ways that increase resource use. The study identifies the need for ' a critical examination of the interactions between actors (e.g. developers, planners, citizens) and of their understandings of eco-developments, competitiveness, and greener cities' (ibid.).

This paper discusses one possible methodological approach to enabling more of the potential for climate mitigation in cities to be realised, and adds to discussions around four of the research questions identified by Sovacool (2014) in the field of energy scholarship in social science. Firstly, Sovacool's research question (2) asks that since human-centred research methods tend to be 'more complex (difficult to fit into a box), expensive, and subjective than others-how can they be improved?' This paper considers how problem structuring methods, a particular type of human-centred research method, can be improved to serve the desired outcomes. Secondly, under the "sociology and history of technology" theme, research question (72) identifies the need to consider the benefits of energy systems for different social groups ('What different social groups are involved in the production of (or may benefit from the use of) a particular energy system?'), and research question (73) considers issues of problem creation, ownership, and fairness in energy decision making ('Which relevant social groups are habitually excluded from energy decisions?') This paper considers these two questions throughout the case study review, but especially in Section 4.4 which presents a reflective study on the main case study. Thirdly, action at the city level brings in the need to consider the "geography and scale" theme, 
and research question (28) considers whether delivery of solutions by a range of actors across society are viable approaches ('Polycentric approaches do not come without risks-how can these be managed, and how can the advantages of decentralization be synergized with those of centralization?') This paper discusses the theme through comparison of the case study results in three cities (section 4.3) and in a discussion on the motivation for participation in low-carbon development by key stakeholders (section $5.2)$.

To guide the reader through the rest of this paper, a brief description of the main sections follows:

- Section 2, Background - Perspectives on Urban Climate Change Mitigation: A review of the literature on the nature of the problem of climate change mitigation at the city level, including barriers to mitigation, ideological perspectives from social science, and governance mechanisms that have been used or recommended in relation to the problem.

- Section 3, Methodology: An introduction to problem structuring methods in general, a description of the five methods that are used in the case study, and a synthesis table that relates the perspectives from section 2 with the methodologies in terms of their synergies and contradictions, benefits and drawbacks.

- Section 4, The STEEP Project: A description of a case study which applied a bespoke methodology based on several problem structuring methods to support energy planning in urban redevelopment, and a reflective study that explored stakeholder engagement issues within the methodology application.

- Section 5, Interpretation of the STEEP Results: An interpretation of the case study results, including a discussion of the applicability and effectiveness of the methodology in the problem context.

- Section 6, Discussion: A discussion that presents the three key themes emerging from the case study and the review of the literature, with some possible ways forward in improving methodology.

- Section 7, Conclusions: Conclusions from the case study and the discussion, and recommendations for future work.

\section{Background - Perspectives on Urban Climate Change Mitigation}

This section provides a high-level review of how climate change mitigation in cities is framed from different viewpoints. We first discuss a view of the problem as wicked and its characteristics, then review some of the identified barriers to emissions reductions. As an overview of current thinking on the problem, several ideological perspectives and governance mechanisms that can be used to manage real-world change are described. 


\subsection{A Wicked Problem}

In this paper we view the challenge of city-scale emissions reductions through the lens of Rittel and Webber's (1973) definition of "wicked", which has been highly cited in the literature. Rittel and Webber describe the problem of planning in social systems as wicked, and problems which can be addressed through disciplines such as engineering as tame. They state that wicked problems are not "solvable" but can, at best, be 're-solved - over and over again' (Rittel \& Webber 1973). Peterson (2009) summarises the original definition of a wicked problem as characterised by several features: 'no definitive formulation of the problem exists; its solution is not true or false, but rather better or worse; stakeholders have radically different frames of reference concerning the problem; constraints and resources for solution change over time; and, the problem is never solved' (Peterson 2009). Head and Alford state that the level of wickedness increases with uncertainty about the problem, the diversity of the parties involved and the amount of conflict between them; wickedness is seen in situations with high 'social pluralism (multiple stakeholder interests and values), institutional complexity, and scientific uncertainty' (Head \& Alford 2008).

Climate change is described as a wicked problem by Bailey (2011) in a critique of ecological modernisation, who states that the uncertainty about how to respond to the science is partly due to the problem having causes and consequences that are systemic in nature. Gollagher and Harz-Karp state that 'issues of non-sustainability are wicked problems that have many, often obscure causes, and for which there is no single, straightforward solution' (Gollagher \& Hartz-Karp 2013). The Australian Public Service Commission (2007) view climate change as a wicked problem from the perspective of public policy, describing the public debate about climate change as three contrasting stories: "profligacy“ (structural inequalities), "lack of global planning", and "much ado about nothing". Since these stories encompass normative beliefs and none of them is completely wrong or completely right, they cannot be changed through exposure to scientific facts, leaving policy makers with a 'dynamic, plural and argumentative system of policy definition' (ibid.).

Recognising the wickedness of a problem situation allows for the acknowledgement that interventions that can work well for tame, or tractable problems are unlikely to succeed. This is a necessary step for beginning to seek more effective methods, and we return to the subject of wicked problems in the Discussion. We first review relevant research on barriers, ideological perspectives and governance mechanisms in the literature, before introducing the methodology and results from our case study.

\subsection{Barriers to Mitigation}

A good deal of work on barriers to climate change mitigation at different scales exists in the literature. Some studies are focused on energy demand management, including energy efficiency, and some on low-carbon generation. Interventions have been proposed and evaluated at the household, organisational, city, and national levels. Sorrell et al. (2004) developed a taxonomy of barriers to energy 
efficiency based on economic, behavioural and organisational theories. Several papers are reviewed here that are more relevant for this paper.

Regarding the energy conservation actions of individuals, Weber (1997) states that barriers cannot be fully understood - they are real but not observable. Barriers have many aspects: institutional, economic, organisational and behavioural. They might be internal to an individual (e.g. lack of knowledge, an absence of motivation) or out of the control of the individual (e.g. new behaviour is not convenient or affordable). Shove (2010) questions the basic theory used in energy management programmes, calling for the reopening of 'a set of basic questions about the role of the state, the allocation of responsibility, and in very practical terms the meaning of manageability, within climate-change policy'. At the social scale, Foxon and Pearson identified the need to address barriers to diffusion of cleaner technologies through systems thinking. They name four types of system failure: failures in infrastructure provision and investment: transition failures, lock-in failures; and institutional failures. Their recommendations for policy change include: 'Developing and applying the concept of 'systems failures' as a rationale for public policy intervention; (ii) Taking advantage of the appearance of 'techno-economic' and 'policy' windows of opportunity; (iii) Promoting a diversity of technology and institutional options to overcome 'lock-in' of unsustainable technologies and supporting institutions' (Foxon \& Pearson 2008).

Parthan et al. (2010) state that a large number of barriers - within the realms of policy, regulation, financing, and business frameworks - prevent the accelerated development of low-carbon energy technology markets, and that cities provide opportunities to achieve low-carbon transition through a focused, area-based approach; however, low-carbon energy planning needs to be integrated into urban planning for policy areas such as transportation, buildings, water supply, electricity and heat. Regarding urban re-development in particular, several authors have commented on the difficulties in making it low-carbon. Within recent brownfield regeneration projects in the UK the sustainability agenda has been met with continual scepticism (Dixon 2007), the integration of sustainability into building developments remains a contested concept (Dixon 2006), and there are ambivalent attitudes towards "sustainable development" at all levels of governance, with continual efforts to reinterpret or compromise the concept to prioritise economic development instead (Couch \& Dennemann 2000).

\subsection{Ideological Perspectives}

Several ideological perspectives have been proposed as a vision or a rationale for guiding climate change mitigation actions; three examples follow which apply at the universal, state, and city levels.

\subsubsection{Ecological Modernisation}

Ecological Modernisation (Bailey et al. 2011) has been a dominant theme in the field of climate change mitigation. It proposes that policies for economic development and environmental protection can be combined to synergistic effect, creating a positive-sum game between economy and ecology (Berger et al. 2001). The ideal of transforming energy systems through ecological modernisation is difficult to 
achieve in reality, however, and at the local scale it can often look like a zero sum game rather than a win-win (Pellow et al. 2000). Within a neoliberal economy such as the UK's, public and private decision making is normally based on a cost-benefit analysis of some type (Attwater 2000) and if emissions are not priced sufficiently high this limits achievement of savings. Whilst there are many economically viable actions that can be taken under the banner of ecological modernisation, such as improving energy efficiency in buildings, the total potential size of these types of win-win solutions is limited. More ambitious emissions reductions will require investments that have much longer paybacks, or even paybacks of a non-monetary kind such as reduced future risk.

\subsubsection{Eco-State Restructuring}

While et al. (2010) have proposed the notion of eco-state restructuring as a response to the lack of theorisation of ecological issues in regulation and institutional economics, and a lack of theorisation of state regulation in environmental governance and ecological modernisation. The concept looks at the ways in which environmental policy is located within the collection of strategies at the state level, and at how environmental regulations have come about through processes of struggle, negotiation and compromise between different stakeholders. The purpose is to contribute to a new type of state political ecology that could better respond to the ever-expanding scope of environmental pressures and demands that states are facing. A study of urban sustainability fixes (While et al. 2004) found that local governments are responsible for reducing the ecological footprint of their cities and also for promoting economic development - even while there are increasing pressures to lower environmental regulation to be able to succeed amidst strong inter-urban competition and new pressures from increased flows of resources and people. While ecological modernisation is the politically acceptable way to "green" urbanised capitalism there is a 'lack of incentives for radical approaches to environmental sustainability in a national urban policy configured around the search for increased consumption' (While et al. 2004).

\subsubsection{Urban Political Ecology}

Urban political ecology, based partly on work from scholars in the Marxist tradition, seeks to understand the workings of power through discussing the infrastructure, networks and flows which "naturalise and hide the socio-ecological relationships that make urban life possible' (March \& Ribera-Fumaz 2014). The urban political ecology perspective conceptualises the urban environment as a socio-natural hybrid' (ibid.), an expression of the power relations that have led to its creation and in which there is co-evolution with technological artefacts. Heynen et al. (2006) describe issues related to socioenvironmental sustainability as being fundamentally political issues, with political ecology seeking to answer questions about who or what needs to be sustained and how it can be achieved. Jonas et al. (2011) describe urban political ecology as 'a concerted attempt to reconceptualise processes of capitalist urbanisation in terms of nature-society metabolisms, environmental justice and ecological politics' - which has become a pressing concern as city governments around the world search for institutional solutions to the tensions between economic development, managing consumption and 
achieving environmental sustainability. The authors highlight the need for a new critical understanding of the place of cities within the whole economic system, especially with regard to the 'search for exchange value through interurban competition' (ibid.), and how "carbon control” (While et al. 2010) could enable urban society to 're-engage with its essential environmental underpinnings'(Jonas et al. 2011).

\subsection{Governance Mechanisms}

Several mechanisms have been described as suitable for governance of low-carbon transition at different scales; three examples follow.

\subsubsection{Intersectoral Collaboration}

Since greenhouse gas emissions are caused by the actions of people and organisations at all levels of society, implementing climate change mitigation at the scale of the city almost always includes some elements of intersectoral collaboration, with the sectoral division being by ownership/control (private, public, community, or variants) and/or by policy sector (e.g. health, transport, infrastructure) (Taket \& White 2000). Huxham (1991) describes four requisite conditions for successful intersectoral collaboration: participants must (i) believe in the importance of collaboration, (ii) agree that the issue is important to themselves and worth collaborating over, (iiii) recognise the right of the others in the collaboration to a part of it, and (iv) have appropriate expectations about what can be achieved. When viewing existing global or national climate change mitigation interventions such as the 2015 COP21 and the UK's Committee on Climate Change we assert that not all of these four conditions have yet been met. For example, in discussing the published expectations about what will be achieved from the COP21 meeting in Paris one mitigation expert stated that: 'the almost euphoric atmosphere that accompanied the drafts could not be squared with the content' (Anderson 2015).

\subsubsection{Collaborative Governance}

Collaborative governance 'brings public and private stakeholders together in collective forums with public agencies to engage in consensus-oriented decision making' (Ansell \& Gash 2008). Ansell and Gash find that the existence of interdependence between agencies leads to a desire to participate and a commitment to meaningful collaboration; conversely, building trust is difficult in cases where interdependence is weak. Trust and interdependence are shaped in positive or negative ways by the collaborative governance process itself. Gollagher and Hartz-Karp (2013) describe "Deliberative Collaborative Governance" (a hybrid of collaborative governance and deliberative democracy) as a process that can allow communities to achieve more resilience and sustainability through shared responsibility, authority, and power, coupled with a pragmatic, problem-solving orientation to wicked problems that emphasises deliberative analysis, fact-finding, and policy evaluation'. An evaluation of collaborative governance for managing water resources in California found that the process needs to involve a mixture of institutions that can 'provide sufficient responsibility, accountability and 
democratic legitimacy, without choking off the self-organizing interaction, shared learning, and communication' (Kallis et al. 2009). The study identified an incompatibility between further growth in the region and environmental conservation, with win-win solutions unlikely to be sufficient to deal with these competing demands and more radical changes necessary but unlikely due to the political situation. Brown (2002) describes an Australian case study in collaborative governance that created an integrated governance framework for managing an ongoing environmental management issue in forestry. Previous approaches used by government had involved them turning first to industry and then to environment NGOs; in this case 'industry and NGOs themselves closed the policy gap' (ibid.).

\subsubsection{Voluntary Agreements}

One example of intersectoral collaboration involving cooperation between public authorities and the private sector is within voluntary agreements that aim to achieve energy savings and emissions reductions via energy efficiency in industry. Rezessy and Bertoldi (2011) examined the success of this approach, reviewing voluntary agreements enacted in different industrial sectors across the EU. Longterm voluntary agreements have shown good results in terms of savings. Compared to regulation, voluntary agreements are more flexible and more acceptable to industry, but they have been criticised for a lack of specific obligations, lenient targets, and deficiencies in compliance monitoring. The authors recommend a framework for designing voluntary agreements that includes ambitious but realistic targets, a public authority with appropriate statutory powers to be in charge of the agreement, an effective and independent monitoring evaluation mechanism, and credible and enforceable mechanisms to discourage non-compliance.

\section{Methodology}

This section introduces the methodology for the case study presented in Section 4 . We first define the general classification of problem structuring methods, then introduce the five methods used within the case study, and finally describe the case study methodology which was developed based on several of the problem structuring methods presented here.

\subsection{Problem Structuring Methods}

Problem structuring methods (PSMs) are a set of methods that are designed to work with and improve the functioning of "people systems" - e.g. organisation or multi-organisational collaborations. PSMs were developed in the light of the failings of traditional Operational Research methods to adequately address wicked problem situations, particularly those that have strong aspects of stakeholder pluralism; for this reason they are often referred to as Soft Operational Research methods (Mingers 2011). They provide a well theorised approach to intervening in such situations. PSMs are generally not used with the expectation of achieving definitive "problem solving" but are more commonly used to reduce uncertainty and "tame" a problem (Rittel \& Webber 1973). The methodologies generally follow a 
process of establishing a shared understanding of the problem situation, capturing and diagrammatically representing diverse points of view about the problem, and then exploring the problem through system modelling techniques, group work and analysis (Ackermann 2012). The benefits of PSMs include developing a common language to describe and discuss the problematic situation and helping stakeholders to reach consensus on what actions should be taken as interventions (Ackermann 2012). PSMs may be formally defined - for example, Soft Systems Methodology (SSM), Strategic Options Development and Analysis (SODA) and Strategic Choice (Ackermann 2012) - or may be observed in action as non-codified instances, in which case their use is empirically deduced by observing their defining characteristic behaviours in operation. A generic constitutive definition of PSMs, cataloguing these characteristic behaviours, has been defined by Yearworth and White (2014).

\subsubsection{Problematisation and Interessement}

White (2009) identifies several conceptual tools that can be used to analyse PSM interventions, including two terms that describe processes carried out within a PSM intervention (originally from Callon (1986) in the field of Actor Network Theory) that are useful for this paper: (i) "Problematisation", asking what the problem is that needs to be addressed and who the relevant actors are; and (ii) "Interessement", gaining interest from the relevant actors and negotiating beneficial involvement. Kawalek et al. (2003) state that the motivation to change arises from stakeholder perception of there being a problem, which necessarily involves (i) a recognition that the problem exists, and (ii) a recognition that they are indeed stakeholders in the problem, since they will be affected by it and/or they could have a role in resolving it. This highlights the importance of problematisation to a change process.

\subsubsection{PSMs in Multi-Agency Settings}

Most PSMs were originally developed to meet a need for pragmatic management interventions in single organisations (Mingers \& Rosenhead 2004), but they are increasingly being used within multi-agency teams (e.g. see (Franco 2009)). For example, the Strategic Choice Approach, which was originally created by Friend and Hickling (1997), has been used in this way. The benefits of using Strategic Choice Approach in a multi organisational team include 'an increased mutual understanding of each other and of the problem domain... high level of support and ownership demonstrated by the participants to the agreements reached... accommodations in the power base of actors' (Franco 2008). However, this application presents particular challenges to the facilitator due to the increased level of potential for conflict about the issues, goals and values that are relevant to the multiple organisations, and the need for the facilitator to achieve legitimacy with all the members of the multi organisational team (Franco 2009). 


\subsubsection{PSMs at the Community Scale}

PSMs can be effective in community situations in which there is disagreement within members of a group about strategy or direction, or in which a group needs to devise a negotiating strategy to deal with external volatility or hostility (Mingers \& Rosenhead 2004). There is a relatively small set of case studies that use PSMs at the scale of a city or community. Bell and Morse (2007) find that PSMs are infrequently used in 'areas of wide ranging and highly complex human activity-specifically those relating to sustainability, environment, democracy and conflict'. This infrequent use is partly due to the cost and complexity ${ }^{1}$ of implementing the methods at this scale. Three example case studies follow.

White and Lee (2009) used a combination of systems thinking, trilemma analysis and problem structuring to work with local stakeholders on the future of their city as a sustainable city. A "trilemma" 'represents a situation of three conflicting choices or pathways in which a resolution that satisfies all three (often conflicting) objectives is sought' (ibid.). The approach taken in the case study allowed stakeholders to work with complexity and uncertainty (particularly the social dimension); multiple and often conflicting stakeholder values; and political effects (e.g. on the city's wider community). Through focusing on sustainable development at the city scale, participants were able to establish a geographical boundary for the problem and consider inter-generational issues - which are rarely dealt with.

Hector et al. (2009) developed an approach to problem structuring for sustainable development. They first present a taxonomy for complex problems that identifies three fundamental problem types. Sustainable development is identified as a type 3 problem - problems which have fundamental complexity, uncertainty and unknowability and cannot be solved through analytical methods but require engagement with diverse stakeholders that have conflicting worldviews. The methodology presented uses the concept of trilemmas to construct a system map of a complex problem space and test stakeholder assumptions through reviewing system boundaries. Results from a case study suggest that it would provide most value to steering and project management teams, rather than to broad groups of stakeholders.

Gregory et al. (2013) applied Complex Adaptive Systems theory (Holland 1992) to inform the development of PSMs, especially in the context of marine management - a wicked problem involving interactions between natural systems, designed systems and social systems. The authors found that the nature of the problem as a complex adaptive system led to a need for tools that can be used for elicitation of knowledge and problem structuring; within the context of the marine environment a broad range of stakeholders needs to be recognised - which is a question of boundary critique; competing knowledge

\footnotetext{
${ }^{1}$ We have used the word "complexity" in this article to indicate that a system is both complicated (many interconnected elements) and has emergent properties which make managing it difficult.
} 
(economic, local and scientific) and value claims must be considered; there is a need to give critical consideration to questions of breadth and depth of participation.

\subsection{Soft Systems Methodology}

Soft Systems Methodology (SSM), created by Checkland (e.g. (Checkland \& Scholes 1990), (Checkland 2000)) is a PSM that follows an iterative process of inquiry and action for improving unstructured problem situations. It is most often used within organisations or in multi-agency settings. In SSM, systems models are assumed to be 'devices, unintellectual constructs to help debates' (Checkland \& Holwell 2004). Four main activities make up the SSM process, as described in (Checkland \& Scholes 1999):7 (i) finding out about a problem situation; (ii) formulating some relevant purposeful activity models; (iii) debating the situation, and using the models to find changes that would improve the situation and create accommodations between conflicting interests; and (iv) taking action in the situation to bring about improvement. One of the key tools within SSM is the Root Definition a concise description of the core purpose of a relevant system (Checkland 1981). The root definition is defined using the CATWOE acronym as follows: (i) Customers - those affected by the transformation; (ii) Actors - those responsible for bringing about the transformation; (iii) Transformation - describing the desired change in the state of an entity (e.g. a city district); (iv) Weltanschauung - the worldview or cognitive orientation of the group of actors trying to achieve the transformation; (v) Owner - those who could prevent the transformation taking place; (vi) Environment - all of the external factors that constrain or enable the transformation to take place. The use of SSM in the field of energy planning was first suggested by the INESC Coimbra group at the Universidade de Coimbra (Coelho et al. (2010), Neves et al. (2004), and Lopes et al. (2015)).

\subsection{Group Model Building}

Group model building is the process of building or refining a systems model by working directly with a small group of experts and/or representatives from a client organisation (((Andersen et al. 2007), (Andersen \& Richardson 1997), (Vennix 1996))). Benefits of the group model building approach include: (i) avoiding the problem of the consultant being an "expert modeller", in which clients may not believe or trust a model built by an external consultant, (ii) enabling the incorporation of a "richer and more informative body of information that exists in the knowledge and experience of those in the active, working world" (Forrester 1991), (iii) allowing for a range of expertise and a variety of views from people with different backgrounds to be included, including their understanding of what causality is present in the system.

\subsection{Hierarchical Process Modelling}

The essence of problem structuring methodology is the use of a jointly developed system model to organise thinking about how a transformation can be achieved. Hierarchical process modelling is a PSM 
that involves decomposing goals into a number of sub-processes, which provide further detail or insight into how the transformation is to be achieved. Although the model is constructed hierarchically, the 'sub-processes' should be thought of as existing in 'part-of' relationship to their 'superior' process i.e. each process in the model can be considered a whole system in its own right (a holon). The model can be thought of as a recursive description of a transformational system, specified at sufficient level of depth that all of the 'how' questions are surfaced during the process of modelling (STEEP Project 2015).

Hierarchical process modelling provides a graphical interpretation of process performance using the socalled "Italian Flag" notation; this is based on the use of interval numbers and Interval Probability Theory ((Hall et al. 1998), (Marashi \& Davis 2006), (Marashi et al. 2008)). In the STEEP project the Italian Flag notation was modified from its quantitative, functionalist roots so that it represented process performance as either good (green), poor (red) or unknown (white), with the inclusion of unknown providing an explicit capture of epistemic uncertainty. To create the hierarchical process models, participants in the group model building workshops simultaneously debated how/why questions about system structure in a dialectical process, leading to them develop a shared understanding both of the problem context and also how the transformational system would lead to achieving an improvement. The process is iterative and continues over a number of workshops.

\subsection{Action Planning}

Hierarchical process modelling is used as a "device" to help understanding, but it can also be used to help develop action planning. This can be done through the workshop participants deciding where specific attention should be placed in the system in order to achieve change with high efficacy. Within STEEP, action planning was done by the groups debating and deciding upon possible options to address poor performance, or what additional work could fill in the identified unknowns. As a final step, workshop participants debated possible intervention options along with arguments for and against their use. These action plans were then taken into the city councils' planning processes.

\subsection{Critical Systems Heuristics and Boundary Critique}

Critical Systems Heuristics (CSH) was developed originally by Ulrich ((1988), (2003)) and later further developed by others ((Midgley et al. 1998), (Reynolds 2008)). CSH is an example of an emancipatory systems method ${ }^{2}$, a class of methods that seek to ensure fairness in terms of empowerment and emancipation (Jackson 2006). One of the key concepts in CSH is the "reference system" which informs the views of stakeholders on the problem situation, and is defined as 'the context that matters when it comes to assessing the merits and defects of a proposition' (Ulrich \& Reynolds 2010). The process of

\footnotetext{
${ }^{2} \mathrm{CSH}$ fulfils the requirements of a PSM in that it covers most of the generic constitutive definition from (Yearworth \& White 2014).
} 
drawing boundaries constrains the ethical stance taken when planning an intervention and so critical reflection about boundary judgments allows the analysis of the ethical consequences of different possible actions (Midgley 2003). There are two main components within the process of CSH: (i) structured stakeholder inquiry or boundary critique, and (ii) the employment of boundary judgments to inform critical debate in which citizens can challenge planners (Jackson 2003). Only the first method was used in this research.

Boundary critique ${ }^{3}$ is usually carried out to reveal the reference systems of different stakeholder groups in relation to some type of intervention, scheme or proposition that is being planned - a generic purposeful system. To reveal different aspects of stakeholders' boundaries of perception, CSH considers what types of boundary exist and what sources of influence on the proposed purposeful system exist within the stakeholder worldview. CSH defines three categories or types of boundary: (i) stakeholders (social roles); (ii) stakes (the 'core interests or concerns associated with a particular stakeholder group' (ibid.); and (iii) stakeholdings (in which stakes are 'relational attributes' that can be constructed, defended, and promoted by stakeholders). CSH defines four sources of influence: (i)'Sources of motivation - where a sense of purposefulness and principle value comes from; (ii) sources of controlwhere the necessary resources and power are located; (iii) sources of knowledge - where sufficient expertise and experience is assumed to be available; (iv) sources of legitimacy - where social and legal approval is assumed to reside' (Reynolds \& Holwell 2010).

Combining the three boundary categories and the four sources of influence creates twelve unique 'constituents to a generic purposeful system' (Reynolds 2008). These twelve constituents can be revealed through asking twelve guiding boundary questions (Ulrich 2001) of each stakeholder group through structured or semi-structured interviews with group representatives. The twelve questions can be used in a heuristic manner to question what a system is and what it ought to be (Midgley et al. 1998), and comparing the answers from different stakeholder groups reveals the (possibly unstated or unobserved) tensions between their reference systems. Maru and Woodford applied the principles of CSH to sustainable development, finding that emancipatory systems methodologies are needed to deal with 'institutionalized asymmetry of power and issues of intra- and intergenerational equity'(Maru \& Woodford 2001). While they found that CSH provides practical tools for revealing underlying values and other assumptions that are built in to sustainable development, the method needs to be improved to be able to challenge institutional belief systems in relation to sustainable development.

\footnotetext{
${ }^{3}$ This section is based largely on an application of boundary critique by Reynolds (2008) in the context of corporate social responsibility.
} 


\subsection{Synthesis of Key Ideas}

To highlight the inter-relationships and overlaps between the different approaches that have been discussed so far, a synthesis of key ideas is shown in Table 1. Some comparisons between them as alignments or contradictions have been identified, but this is by no means a complete analysis. Table 1 serves as a framework for understanding our empirical research and relates the approach used in the case study to other approaches used in the social science field.

\begin{tabular}{|c|c|c|c|c|}
\hline Name & Key Ideas & Type & Benefits/Alignments & $\begin{array}{c}\text { Drawbacks/ } \\
\text { Contradictions }\end{array}$ \\
\hline Wickedness & $\begin{array}{l}\text { Some problem situations have } \\
\text { certain characteristics that } \\
\text { make them not respond well } \\
\text { to reductionist approaches }\end{array}$ & Classification & $\begin{array}{l}\text { Aligned with most of the } \\
\text { ideological perspectives and } \\
\text { many authors' findings about } \\
\text { the nature of the } \\
\text { sustainability problem }\end{array}$ & $\begin{array}{l}\text { Most perspectives } \\
\text { acknowledge the existence } \\
\text { of wickedness in problem } \\
\text { situations but there are few } \\
\text { methods that can address } \\
\text { it reliably }\end{array}$ \\
\hline $\begin{array}{l}\text { Interessement } \\
\text { and problemati- } \\
\text { sation }\end{array}$ & $\begin{array}{l}\text { The willingness / interest in a } \\
\text { problem, which leads to the } \\
\text { participation of an agency or } \\
\text { person in seeking to } \\
\text { understand or solve the } \\
\text { problem - i.e. make it a } \\
\text { problem for them }\end{array}$ & Concept & $\begin{array}{l}\text { Important aspect of any } \\
\text { intersectoral interactions, } \\
\text { and in filtering down the } \\
\text { sustainability agenda to the } \\
\text { city, governance, and } \\
\text { organisational levels }\end{array}$ & $\begin{array}{l}\text { Often not recognised due } \\
\text { to unawareness of the } \\
\text { reference systems of } \\
\text { stakeholders }\end{array}$ \\
\hline $\begin{array}{l}\text { Ecological } \\
\text { modernisation }\end{array}$ & $\begin{array}{l}\text { The economy can be made } \\
\text { sustainable through improving } \\
\text { and modernising technology; } \\
\text { questioning of economic goals } \\
\text { is not necessary }\end{array}$ & $\begin{array}{l}\text { Ideological } \\
\text { Perspective }\end{array}$ & $\begin{array}{l}\text { Allows sustainability action } \\
\text { within the neoliberal political } \\
\text { system }\end{array}$ & $\begin{array}{l}\text { Eco-state restructuring } \\
\text { identifies a lack of } \\
\text { theorisation from this field; } \\
\text { limited potential for change } \\
\text { if only win-wins are } \\
\text { implemented }\end{array}$ \\
\hline $\begin{array}{l}\text { Eco-state } \\
\text { restructuring }\end{array}$ & $\begin{array}{l}\text { Governance of states needs } \\
\text { to be restructured to include } \\
\text { consideration of sustainability } \\
\text { issues }\end{array}$ & $\begin{array}{l}\text { Ideological } \\
\text { Perspective }\end{array}$ & $\begin{array}{l}\text { Argument is supported by } \\
\text { the evidence of } \\
\text { underperformance of } \\
\text { mitigation efforts; aligns with } \\
\text { collaborative governance }\end{array}$ & $\begin{array}{l}\text { Influenced by particular } \\
\text { types of urban political } \\
\text { ecology. Needs a } \\
\text { structured approach to } \\
\text { achieve real world change }\end{array}$ \\
\hline $\begin{array}{l}\text { Urban political } \\
\text { ecology }\end{array}$ & $\begin{array}{l}\text { The urban political sphere can } \\
\text { be examined in terms of } \\
\text { human power structures and } \\
\text { this will enable more } \\
\text { sustainability transition }\end{array}$ & $\begin{array}{l}\text { Ideological } \\
\text { Perspective }\end{array}$ & $\begin{array}{l}\text { Deals with underlying power } \\
\text { issues that can block } \\
\text { sustainability transition. } \\
\text { Aligns with CSH. }\end{array}$ & $\begin{array}{l}\text { Not clear what methods } \\
\text { could be used to challenge } \\
\text { power structures or } \\
\text { situations it would be } \\
\text { suitable for. }\end{array}$ \\
\hline $\begin{array}{l}\text { Collaborative } \\
\text { Governance }\end{array}$ & $\begin{array}{l}\text { When agencies, including } \\
\text { government, NGOs and } \\
\text { companies, collaborate to } \\
\text { create new forms of } \\
\text { governance they can better } \\
\text { manage environmental issues } \\
\text { and achieve change }\end{array}$ & $\begin{array}{l}\text { Governance } \\
\text { mechanism }\end{array}$ & $\begin{array}{l}\text { Provides a better way to } \\
\text { manage sustainability issues } \\
\text { than top-down or } \\
\text { government-led initiatives. } \\
\text { Could align with urban } \\
\text { pollical ecology in shifting } \\
\text { some power to others. }\end{array}$ & $\begin{array}{l}\text { Only likely to succeed in } \\
\text { particular situations } \\
\text { (agencies are } \\
\text { interdependent). Can be } \\
\text { time consuming and } \\
\text { requires high levels of } \\
\text { commitment. }\end{array}$ \\
\hline $\begin{array}{l}\text { Intersectoral } \\
\text { Collaboration }\end{array}$ & $\begin{array}{l}\text { Social-level problems can } \\
\text { only be addressed when there } \\
\text { is collaboration between } \\
\text { sectors but this requires } \\
\text { commitment and a willingness } \\
\text { to engage }\end{array}$ & $\begin{array}{l}\text { Governance } \\
\text { mechanism }\end{array}$ & $\begin{array}{l}\text { Similar to collaborative } \\
\text { governance but less } \\
\text { transformative; can be } \\
\text { achieved within current } \\
\text { political landscape, essential } \\
\text { for PSMs at social scale }\end{array}$ & $\begin{array}{l}\text { Assumes there is a reason } \\
\text { to collaborate and agency } \\
\text { to act, which may not exist } \\
\text { with regard to sustainability }\end{array}$ \\
\hline $\begin{array}{l}\text { Voluntary } \\
\text { Agreements }\end{array}$ & $\begin{array}{l}\text { Win-wins can be achieved } \\
\text { when agreements between } \\
\text { agencies (often industrial) are } \\
\text { entered into voluntarily with a } \\
\text { clear goal and measurable } \\
\text { outcomes }\end{array}$ & $\begin{array}{l}\text { Governance } \\
\text { mechanism }\end{array}$ & $\begin{array}{l}\text { Aligns with ecological } \\
\text { modernisation, in } \\
\text { implementing resource } \\
\text { savings in specific realms } \\
\text { without challenging status } \\
\text { quo }\end{array}$ & $\begin{array}{l}\text { Partly dependent on } \\
\text { appropriate regulation and } \\
\text { economic rules - would } \\
\text { benefit from eco-state } \\
\text { restructuring }\end{array}$ \\
\hline
\end{tabular}




\begin{tabular}{|c|c|c|c|c|}
\hline Name & Key Ideas & Type & Benefits/Alignments & $\begin{array}{l}\text { Drawbacks/ } \\
\text { Contradictions }\end{array}$ \\
\hline $\begin{array}{l}\text { Problem } \\
\text { structuring } \\
\text { methods }\end{array}$ & $\begin{array}{l}\text { "People systems" can be } \\
\text { improved through establishing } \\
\text { a shared understanding of the } \\
\text { problem situation, } \\
\text { diagrammatically representing } \\
\text { diverse points of view, and } \\
\text { using systems modelling } \\
\text { techniques and group work }\end{array}$ & Classification & $\begin{array}{l}\text { In theory, PSMs could } \\
\text { support the application of all } \\
\text { of the ideological } \\
\text { perspectives described here. } \\
\text { Could support practical } \\
\text { interventions in infrastructure } \\
\text { changes }\end{array}$ & $\begin{array}{l}\text { Little experience at the } \\
\text { social scale in } \\
\text { implementing change. } \\
\text { Requires commitment to } \\
\text { participate from } \\
\text { stakeholders over time to } \\
\text { achieve full benefits }\end{array}$ \\
\hline $\begin{array}{l}\text { Soft Systems } \\
\text { Methodology }\end{array}$ & $\begin{array}{l}\text { Can improve complex people } \\
\text { system problems through an } \\
\text { iterative process of enquiry } \\
\text { and can bring clarity to a } \\
\text { transformation }\end{array}$ & $\begin{array}{l}\text { Methodology } \\
\text { (PSM) }\end{array}$ & $\begin{array}{l}\text { Can support sustainability } \\
\text { transformation within } \\
\text { organisations and strategic } \\
\text { sustainability policy }\end{array}$ & $\begin{array}{l}\text { Requires expert facilitation } \\
\text { and difficult to do at an } \\
\text { intersectoral or social scale }\end{array}$ \\
\hline $\begin{array}{l}\text { Group Model } \\
\text { Building }\end{array}$ & $\begin{array}{l}\text { Can develop new insights and } \\
\text { go beyond restricted } \\
\text { worldviews by creating } \\
\text { models together in a } \\
\text { multidisciplinary team }\end{array}$ & $\begin{array}{l}\text { Method } \\
\text { (PSM) }\end{array}$ & $\begin{array}{l}\text { Can support most other } \\
\text { PSMs and allow progress in } \\
\text { difficult, pluralist situations } \\
\text { and in understanding wicked } \\
\text { problems }\end{array}$ & $\begin{array}{l}\text { Requires good facilitation } \\
\text { and a willingness to } \\
\text { participate in what can be } \\
\text { a messy process }\end{array}$ \\
\hline $\begin{array}{l}\text { Hierarchical } \\
\text { Process } \\
\text { Modelling }\end{array}$ & $\begin{array}{l}\text { Allows complex problems to } \\
\text { be broken down into smaller } \\
\text { processes, which leads to } \\
\text { identification of suitable and } \\
\text { practical actions }\end{array}$ & $\begin{array}{l}\text { Methodology } \\
\text { (PSM) }\end{array}$ & $\begin{array}{l}\text { Can support ecological } \\
\text { modernisation goals and } \\
\text { clearly defined intersectoral } \\
\text { goals. }\end{array}$ & $\begin{array}{l}\text { Less dynamic than other } \\
\text { PSMs; may require some } \\
\text { soft systems or crucial } \\
\text { thinking before starting }\end{array}$ \\
\hline Action planning & $\begin{array}{l}\text { Identifies the best actions to } \\
\text { take to achieve the identified } \\
\text { processes, possibly } \\
\text { comparing costs and benefits } \\
\text { of different options }\end{array}$ & $\begin{array}{l}\text { Method } \\
\text { (PSM) }\end{array}$ & $\begin{array}{l}\text { Can be used to find best and } \\
\text { more realistic options. Can } \\
\text { use standard analysis tools; } \\
\text { highlights the necessary } \\
\text { roles of stakeholders }\end{array}$ & $\begin{array}{l}\text { Need to ensure power } \\
\text { structures have been } \\
\text { considered along with } \\
\text { technology/economics }\end{array}$ \\
\hline $\begin{array}{l}\text { Critical systems } \\
\text { heuristics }\end{array}$ & $\begin{array}{l}\text { Need to consider those } \\
\text { without a voice when planning } \\
\text { social level interventions, and } \\
\text { include emancipatory } \\
\text { systemic issues }\end{array}$ & $\begin{array}{l}\text { Methodology/ } \\
\text { philosophy }\end{array}$ & $\begin{array}{l}\text { Aligns with urban political } \\
\text { ecology. Designed to } \\
\text { improve top-down planning } \\
\text { but theory could be applied } \\
\text { to other situations }\end{array}$ & $\begin{array}{l}\text { Not clear whether detailed } \\
\text { consideration of } \\
\text { emancipatory issues will } \\
\text { be helpful in enacting low- } \\
\text { carbon transition }\end{array}$ \\
\hline $\begin{array}{l}\text { Boundary } \\
\text { critique }\end{array}$ & $\begin{array}{l}\text { Need to understand } \\
\text { motivation, power, knowledge } \\
\text { legitimacy for different } \\
\text { stakeholders and identify } \\
\text { where there are tensions } \\
\text { between them }\end{array}$ & $\begin{array}{l}\text { Method } \\
\text { (PSM) }\end{array}$ & $\begin{array}{l}\text { Can support intersectoral } \\
\text { collaborations or } \\
\text { interventions created by } \\
\text { planners to improve social } \\
\text { systems; aligns with urban } \\
\text { political ecology }\end{array}$ & $\begin{array}{l}\text { Established but relatively } \\
\text { unknown method that } \\
\text { requires interpretation and } \\
\text { grounding in the theory, } \\
\text { and access to stakeholders }\end{array}$ \\
\hline
\end{tabular}

Table 1: Synthesis of Key Ideas, Methodologies

Comparing the PSMs in the table with the governance mechanisms, we propose that PSMs can be viewed as, at least in part, an alternative to a governance mechanism. The main difference is that rather than seeking to govern change, a PSM seeks to bring change about by debating the problematic situation and reaching collective agreements about what changes to make. Unlike a governance mechanism that may impose a static framework for achieving change, both in terms of approach and scope, the scope of a PSM changes dynamically through an iterative, cyclical process of debating about the problematic situation and agreeing upon actions. A PSM causes real world actions through creating a shared commitment to take action, with the relationships between the beneficiaries, problem owners and problem solvers (actors) being co-creational and co-dependent.

\section{The STEEP Project}

The STEEP project (Systems Thinking for Efficient Energy Planning, www.smartsteep.eu) was an EU Smart Cities and Communities funded project delivered in a partnership between the three cities of San 
Sebastián (Spain), Bristol (UK) and Florence (Italy). STEEP aimed to develop Energy Master Plans for three city districts ${ }^{4}$ that would overcome the barriers to energy efficiency through adopting a systems thinking methodology in combination with open-data technology. This section describes highlights of the STEEP project methodology and outcomes. Full results can be found in the project evaluation report (Yearworth 2014).

\subsection{The STEEP Methodology}

The STEEP methodology was created from several methods and elements from systems-oriented methodologies and was used to carry out the bulk of the project work in the three cities. Methodology development for STEEP ${ }^{5}$ was guided by the generic constitutive definition of PSMs, as defined in (Yearworth \& White 2014). The methodology focused on structured ways of engaging with the problematic situation of transition to a low-carbon urban district, with respect to the scope of the transformation necessary to achieve the defined transition and its stakeholding (i.e. the transition as a relational attribute that can be constructed, defended, and promoted, or not, by different stakeholders).

The main STEEP methodology incorporated three elements: (i) SSM's process of defining a root definition and transformation, (ii) approaches originating from the group model-building community, and (iii) the use of Hierarchical Process Modelling ${ }^{6}$ as an interpretation of SSM's Purposeful Activity Systems modelling. The essence of participation in the methodology was a series of group model building workshops in which stakeholders developed a shared understanding of the problem the city was trying to address (the transformation) and a model of the system that can be used to enact the transformation. A training course covering the theoretical underpinnings of the methodology and details on how to implement the group model building workshops was delivered to the three project teams in

\footnotetext{
${ }^{4}$ The Temple Quarter Enterprise Zone (TQEZ) in Bristol, Urumea Riverside in San Sebastián, and Cascine Park in Florence.

${ }^{5}$ One of the authors of this paper led the methodology development and evaluation for the whole project, and facilitated the workshops for the Bristol intervention. As a consequence, research data on implementation of the STEEP methodology are only available for the Bristol intervention, whilst evaluation data are available from all three city interventions.

${ }^{6}$ Whilst, unfortunately, we let the original provenance of the modelling approach constrain our presentation of the method to use of the word hierarchical, one of us, as facilitator of the workshops in Bristol, did go to some lengths to help participants think about the relationship between processes as one of containment or 'part of' membership. Processes drawn 'below' and linked to a process 'above' are in fact describing a containment relationship. The process above, contains or comprises the processes below. In this way, if more detail is required to aid understanding then the process can be 'opened up' and its constituent parts then explored. If further detail was not likely to help discussion then the containing process would be considered sufficient detail with which to work. Further explanation was provided to participants to avoid unnecessary reification, i.e. to keep things at a process level. This was considered necessary to maintain conceptual abstraction. For example, if 'mitigating exhaust emissions' was sufficient detail to enable discussion of a problem then participants would have been advised to step-back from reification into naming a specific implementation technology to avoid unnecessary limitation of the process view at that point in time.
} 
San Sebastián, Bristol, and Florence ${ }^{7}$. The cities then worked independently on the design and execution of energy planning transformations. There was considerable flexibility within the remit of the project funding and interpretation of the systems thinking methodology for the cities to organise participation and choose specific areas of the local problem on which to focus.

An additional reflective study was done, only in Bristol, to better understand issues that arose during the application of the STEEP approach, and this had a separate methodology. Since the STEEP project was designed to achieve a specific transformation in three cities, the approach needed to address the cocreational and co-dependent relationship between scope and stakeholding. For this reason, during the reflective study we drew upon methods and concepts that could explore these issues - the concepts of problematisation and interessement (section 3.1.1) and the method of Boundary Critique (section 3.6). Whilst acknowledging that these originate from different intellectual sources, they are two sides of the same coin - both offer a systematic way of exploring a problematic situation with respect to its scope, and therefore its stakeholding - and so we have brought them together here within a practical application.

\subsection{STEEP Bristol Project}

\subsubsection{Bristol Project Background}

The City of Bristol has strong "green" credentials, having established a target for a $40 \%$ drop in carbon emissions by 2020, hosting a thriving green business community, and being the EU Green Capital in 2015. Bristol's Temple Quarter has been targeted for redevelopment, and was awarded Enterprise Zone status in 2012 with targets to create 17,000 new jobs and invest over $£ 200 \mathrm{M}$ in infrastructure grants. Four main partners are involved in redeveloping the Temple Quarter Enterprise Zone (TQEZ): the Local Enterprise Partnership (LEP) which is a regional job creation body; Bristol City Council (BCC) which is the Local Authority; a central government agency that owns six of the undeveloped sites; and Network Rail which runs the railway station located in the zone. Within BCC there are several groups whose work relates to the TQEZ: the City Design group; the Planning Department who develop land use plans and grant planning permission; the Economic Development group; and the group managing the TQEZ development project who liaise with private developers and land owners. There are two aspects to the vision for the redevelopment: a spatial framework provides a plan for the speedy economic development of the TQEZ (Bristol City Council 2012c), whilst the strategic planning

\footnotetext{
${ }^{7}$ A contract requirement made by the EU stipulated that the STEEP methodology should be made "open" and freely available to any other city groups wishing to use it. Accordingly, the training course was video recorded and made public at www.smartsteep.eu/resources. In addition, the development of the methodology, its scalability to smart city planning needs, and its evaluation are documented in STEEP deliverables D2.1, D4.2 and D2.5 respectively and are available for download at www.smartsteep.eu/deliverables.
} 
document for the TQEZ - "A Sustainable Urban Quarter by Design" - lays out a vision of making the TQEZ operationally low-carbon as well as achieving a range of other sustainability goals (Bristol City Council 2013). The STEEP project was carried out in Bristol by four partner organisations: Bristol City Council (BCC), a Building Engineering Consultancy, a Sustainable Planning Consultancy, and the University of Bristol.

\subsubsection{Bristol Project Results}

The results presented here are a summary of an evaluation of the STEEP methodology (Yearworth $2014)^{8}$, which was primarily carried out with a view to methodological learning (Yearworth \& White 2014) and based on approaches suggested by Ormerod (2013) and Midgley et al. (2013). Here we focus on the Purposes and Outcomes dimensions of the Midgley et al framework, specifically focussing on the narrative report for the project.

Stakeholder representation in the Bristol workshops was intentionally multi-agency, which had the concomitant problem of there being a disparity of assumptions, as illustrated by the following quote:

"There was a disparity between values and assumptions, significantly between the assumptions (held by local officers and large organisations) that the TQEZ is a single conceptual entity, whose residents have a unity of purpose with regards to carbon-reduction measures" (Yearworth 2014; p4).

The operating environment of a stipulated enterprise zone and the continuing effects from the financial crisis were clearly operating to constrain BCC:

"The local authority could be said to have been constrained by existing policy requirements, specifically with regards to planning policy, heritage requirements and the stipulations of the status of the TQEZ as an 'Enterprise Zone"' (Yearworth 2014; p4-5).

Overall, whilst the workshops were viewed positively, the net outcome did not lead to actionable interventions:

"The generally stated (and generally held) purpose, of exploring the issues and barriers to achieving a carbon-neutral TQEZ was met. The sessions did not initially yield sufficient detail to allow for further exploration of any specific interventions however." (Yearworth 2014; p5).

From BCC's point of view, there was an expectation that the STEEP methodology would reveal hidden yet actionable business opportunities that would counter the prevailing economic conditions and the

\footnotetext{
${ }^{8}$ Where we have quoted from the deliverable in this section we have attributed the quote to the city (likewise, sentiments, and actions), rather than the specific individual(s) reporting on behalf of their city council.
} 
rules governing enterprise zones. This was not met. However, this is not a dead-end for BCC as they stated:

"There is evidence that methodological analysis of various organizational and behavioural aspects has secured long-term outcomes such as revised governance structures within the TQEZ, and the establishment of a sustainability strategy" (Yearworth 2014; p7).

The final, emergent view of how to achieve the low carbon transformation of the TQEZ is expressed in Figure 1. It shows just the four first-level processes that were identified; i) achieving commercial viability of technologies, ii) achieving technical feasibility, iii) achieving low-carbon mobility, and iv) enabling decision making architecture.

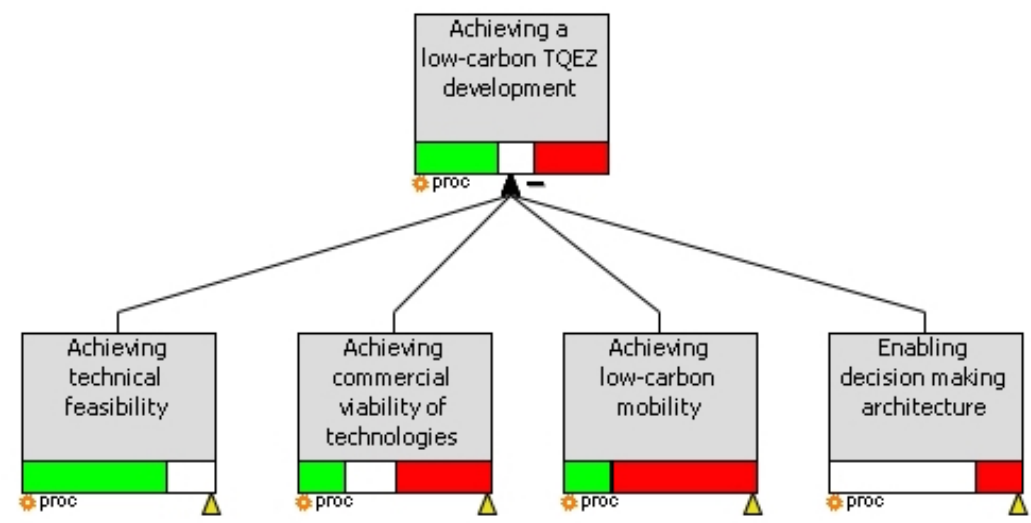

Figure 1: First-level processes of the Bristol System Model, titled "Achieving a low-carbon TQEZ development"

One of the most significant results was the realisation that the process of navigating the decision making architecture, by which is meant the way in which collective, multi-agency decision making could be achieved, was in fact the biggest unknown to the Bristol project members. Achieving the commercial and technically feasibility of possible building solutions and dealing with the problems of mobility around the TQEZ were seen as being less problematic:

“...who owns the transformational process that you're trying - who owns the problem that you're trying to solve? That was and has been a significant issue for us here in Bristol about who exactly has responsibility for our ambitious carbon reductions targets in the zone and the various different aspects" (Yearworth 2014; p16).

\subsection{Cross-City Comparison}

This section compares results from implementation of the STEEP methodology in San Sebastián, Florence and Bristol, highlighting those aspects that made a material difference to its effectiveness. The main STEEP project team were based in Bristol and so we did not gain a detailed view of the governance and policy contexts in San Sebastián and Florence. However, the comparison that follows, on how 
application of the methodology played out, reveals some of the unique cultural, governance and policy contexts in the three cities.

Goal Setting: Bristol and San Sebastián defined transformational goals that respected local stakeholder concerns that ideas of achieving zero-carbon development were untenable. Consequently Bristol focussed on a goal of "low-carbon" without being precise about the definition of low, and in San Sebastián "from the beginning, we didn't try to establish a zero emission situation as a goal, but just to get close enough to it." In Florence, due to two tragic accidents that occurred in the city at the start of the process, a change of goal occurred, with the new goal being something "which we could define as smart and green efficiency plan which was sustainable not only for energy for even for life and security."

Stakeholder Participation: Whilst the three city councils provided the prime motivation for addressing low carbon energy planning in their development districts, they are not the only agencies with power to affect change in the districts. In fact, each has varying degrees of power according to the prevailing legal, planning and ownership situations in their city. Both Bristol and San Sebastián observed problems with maintaining consistency of the stakeholder groups from workshop to workshop. In Bristol, the same organisations were represented from one workshop to the next, but it not necessarily by the same people. In San Sebastián they noted that “we haven't really found the best way of getting everybody, and really having everybody. Because we really think that this model is very much based on who is participating." The focus on action planning was much easier to maintain in Bristol. Florence was only able to hold their stakeholder group together as a consequence of the major change in project scope.

Group Model Building Process: The San Sebastián team attempted a strict interpretation of the STEEP methodology and found it a struggle. The Florence team made no reference to any difficulties, perhaps since they took a more creative approach to its implementation. They started by relating the modelling to a smart city view, rather than an energy efficiency view. "We started a discussion which was a real participatory discussion and in the beginning there was a strong identity of what the stakeholders wanted...so it was quite easy to find the strategies to go together to make synergies from the municipality action or desire and the private action and what they wanted to achieve".

Model Development: The Bristol system model shown in Figure 1 has four main sub-processes that were largely developed independently once they were identified, whereas systems modelling in San Sebastián followed a more integrated approach "Instead of making separated groups and develop them as separated groups, we really operate them in a more integrated way. Because we think that what we are doing, and how we are building in any of those sides, it's already linked. It's already affecting the other parts as well." Bristol and Florence thus both used the system modelling process in the spirit of the soft systems paradigm and with the model being treated as a boundary object; whereas, in San Sebastián there was far more attachment to the model itself. 
Action Planning: San Sebastián and Bristol found it straightforward to use the system modelling approach to develop action plans for interventions and these are articulated in (Yearworth et al. 2015). There were five actions identified from the outcome of the Bristol workshops focussing on issues that emerged from the "Enabling the Decision-Making Architecture" process. This reflected the poor state of awareness of how decisions were being made in relation to developments in the TQEZ, and the perception that this was a process that was not working well either - which can be seen clearly in the Italian Flag for the process in Figure 1. The San Sebastián group identified 22 processes deemed critical, to be further analysed by the city council for actions": "We made a selection of around six, seven interventions that we felt that were the ones that needed to be worked out in first place. The ones that we should prioritise in our master plan."

Other Effects: The system modelling in Florence did not lead to an identified set of actions via the Italian Flag labelling of process performance, but instead the actual process of modelling in the workshop was used to improve participant motivation to work with the city council via the direct involvement of the deputy mayor. This participation meant that stakeholders felt "We really want to achieve a master plan. We really want to obtain a result in the pilot area, and we are really involved with achieving the result of energy efficiency implementation in the park and then in the city."

These differences in how the methodology was implemented, the level of participation from different stakeholders, and the outcomes indicate the dynamic nature of the methodology and how it differs from more top-down approaches. In fact, some of the key benefits were seen in bringing out issues that had not previously been recognised but which were hampering progress towards a low-carbon vision.

\subsection{Bristol STEEP Reflective Study}

The purpose of the reflective study, which used the boundary critique method (section 3.6), was to investigate the issue of problem ownership for Bristol's low-carbon vision, which had become an ongoing uncertainty while carrying out the main STEEP methodology in Bristol.

\subsubsection{Method}

The System of Interest: Boundary critique is most often done to reveal and compare the reference systems of different stakeholder groups in relation to a proposed intervention or scheme. In this case, the intervention is the redevelopment of the TQEZ, and the sustainability vision that has been proposed for it by the Future Cities team at BCC.

\footnotetext{
${ }^{9}$ We have skipped over an extra step in the methodology that used a third-party tool (the Sustainable Project Appraisal Routine

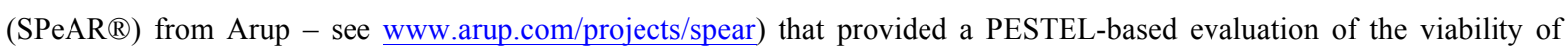
options.
} 
Data sources: Three types of data were gathered. Firstly, a series of semi-structured interviews with representatives from five key stakeholder groups involved in development of the TQEZ was carried out. The interview structure was based on CSH's twelve questions, as described in section 3.6. Secondly, notes from group meetings and workshops were reviewed to pull out any key insights from individuals, or any themes that had emerged through being raised multiple times. Thirdly, publicly available documents were reviewed for any relevant evidence. In particular, since no members of the general public had attended the STEEP workshops, several comments from individual citizens or local business owners published in BCC public consultation documents were reviewed (Bristol City Council 2012b), (Bristol City Council 2012a).

\subsubsection{Summary Table Format and Content Development}

A format for a summary table was developed based on (Reynolds 2008). Each column presents data relevant to one stakeholder group. The meaning of each row in the table is explained as follows:

1. Stakeholder Role: The main goals or responsibilities of the stakeholder group and the agency they have to take actions.

2. Stakeholder group (social role): Who the members of the group are. Categorising stakeholder groups for the purposes of the boundary critique may mean that several organisations are grouped together, or even that different departmental groups within an organisation are considered separately. For example, although BCC are presented in this study as a single stakeholder group, the different departments within the council could have been considered to be separate stakeholder groups since their goals and responsibilities differ significantly in relation to the TQEZ. Practically speaking, it was not possible to gather enough information within the timeframe of this boundary critique study to present different BCC departments as stakeholder groups in their own right ${ }^{10}$.

3. Stake(s) held by the stakeholder group (specific concerns): The high-level concerns for the group in relation to the system of intervention - what key achievements they need to get out of it. Stakes are the 'core interests or concerns associated with a particular stakeholder group relevant to a system' (Reynolds 2008). The stakes that a stakeholder group hold will influence where their willingness for interessement and participation in problematisation.

4. Stakeholding needs (situation oriented) - what's at stake: What is needed for the stakeholder group to protect their stakes in the intervention. These needs will be related to their role and responsibilities within the intervention (what actions they need to take, what metrics they need to

\footnotetext{
${ }^{10}$ In terms of representing a whole group in the boundary critique, we do not assert that all individuals within the groups identified share the same views; only that we have gathered enough data to present a qualitative, interpretivist view about the stakeholder group's role in the TQEZ project. To increase confidence that such a study truly represents the groups, as identified, would require a much larger and statistically robust study carried out with suitable sampling methods.
} 
achieve, etc.), their core business interests, and their relationships with other stakeholder groups. This is about protecting stakes within the intervention to achieve a successful outcome.

5. Stakeholding needs (system oriented) - stakeholding development: What is needed for the stakeholder group to achieve their long-term goals and (for organisations that have one) support their organisational strategy. This is about ensuring the intervention outcomes support their core interests.

The first step in developing content for the summary table was to format the structured interview responses into four tables - as sources of motivation, sources of control, sources of knowledge, and sources of legitimacy - each with three rows, one for each CSH question, and with responses from stakeholders positioned side by side (in line with the approach taken in Reynolds (2008)). The CSH tables were then amalgamated with notes from project meetings and workshop and relevant public documents, through an analysis that identified the most important themes, ideas or definitions. These themes were then formatted to match the table format.

\subsubsection{Summary Table}

Table 2 presents a summary of our findings from the boundary critique. A reading of the table contents across each row reveals where there is alignment or tension between the stakeholder groups in relation to the low-carbon development vision. Some of the identified tensions are illustrated here by quotes from interviewees:

On lack of agreement on the low-carbon vision within BCC: 'There are too many different documents from BCC. Some people haven't bought into the vision at all.' (Interviewee from the Building Engineering Consultancy).

On not setting clear standards: 'If they deliver BREEAM ${ }^{11}$ excellent [buildings] will that be green? Benchmarks keep moving.' (Interviewee from the TQEZ project management group).

On whether political support is there: We need to 'use political rhetoric to secure the aspiration.... The TQEZ is a political tool, a status afforded to an area to support economic growth - its primary function. Planners can work to improve upon building regulations where they see fit, but that is not the main focus.' (Interviewee from STEEP project management within BCC).

On stakeholder priorities: 'Developers will take the lowest risk and the cheapest options.' (Interviewee from the Building Engineering Consultancy). 'Very few levers for BCC to negotiate with. Need to understand the market and "sell" the benefits of low carbon interventions to those that can deliver them.' (Interviewee from the Sustainable Planning Consultancy)

\footnotetext{
${ }^{11}$ BREEAM is a design and assessment method for sustainable buildings (www.breeam.org)
} 
On regulation and attracting investment: 'Part of the TQEZ benefit is simplified planning, which conflicts with adding more regulation to promote green building.' (Interviewee from the Building Engineering Consultancy).

\begin{tabular}{|c|c|c|c|c|c|}
\hline & $\begin{array}{l}\text { Bristol City } \\
\text { Council }\end{array}$ & $\begin{array}{c}\text { Energy Planning } \\
\text { Experts }\end{array}$ & $\begin{array}{l}\text { Regeneration } \\
\text { Implementers }\end{array}$ & $\begin{array}{c}\text { Stakeholder } \\
\text { Groups with } \\
\text { Financial Interests }\end{array}$ & Citizens of Bristol \\
\hline $\begin{array}{l}\text { Stakeholder } \\
\text { Role }\end{array}$ & $\begin{array}{c}\text { Energy master } \\
\text { planning, planning } \\
\text { permission, } \\
\text { economic } \\
\text { development, vision }\end{array}$ & $\begin{array}{l}\text { Expert input into } \\
\text { energy master } \\
\text { planning }\end{array}$ & $\begin{array}{c}\text { Implementing } \\
\text { physical } \\
\text { development }\end{array}$ & $\begin{array}{l}\text { Financial investment } \\
\text { and land provision }\end{array}$ & $\begin{array}{c}\text { Intended } \\
\text { beneficiaries }\end{array}$ \\
\hline $\begin{array}{l}\text { Stakeholder } \\
\text { group } \\
\text { (social role) }\end{array}$ & $\begin{array}{l}\text { Several groups } \\
\text { within BCC (City } \\
\text { Design, planning } \\
\text { dept, economic } \\
\text { development group, } \\
\text { Mayor's office) }\end{array}$ & $\begin{array}{l}\text { Building design and } \\
\text { sustainable planning } \\
\text { consultants working } \\
\text { on STEEP }\end{array}$ & $\begin{array}{c}\text { Development } \\
\text { managers, facility } \\
\text { operators, } \\
\text { architects, } \\
\text { infrastructure cos., } \\
\text { builders, transport } \\
\text { cos. }\end{array}$ & $\begin{array}{c}\text { BCC's economic } \\
\text { development team, } \\
\text { the LEP, the HCA, } \\
\text { Network Rail, } \\
\text { private land owners, } \\
\text { BCC as land owner }\end{array}$ & $\begin{array}{l}\text { Residents, tenants, } \\
\text { building owners in } \\
\text { the TQEZ, people } \\
\text { who will use public } \\
\text { facilities like the } \\
\text { arena }\end{array}$ \\
\hline $\begin{array}{l}\text { Stake(s) held } \\
\text { by the } \\
\text { stakeholder } \\
\text { group } \\
\text { (specific } \\
\text { concerns) }\end{array}$ & $\begin{array}{l}\text { Realising BCC's } \\
\text { vision for the TQEZ } \\
\text { (economic and low- } \\
\text { carbon); political } \\
\text { capital; contributions } \\
\text { to overall Bristol City } \\
\text { sustainability goals }\end{array}$ & $\begin{array}{c}\text { Completing energy } \\
\text { master plan for a } \\
\text { sustainable TQEZ; } \\
\text { improving } \\
\text { stakeholder } \\
\text { engagement in } \\
\text { planning }\end{array}$ & $\begin{array}{l}\text { Successful } \\
\text { commercial } \\
\text { projects, enhanced } \\
\text { reputation, } \\
\text { business } \\
\text { development; } \\
\text { success in } \\
\text { achieving the spatial } \\
\text { framework }\end{array}$ & $\begin{array}{l}\text { Make money out of } \\
\text { developing the } \\
\text { TQEZ; create jobs } \\
\text { and economic } \\
\text { growth for Bristol; } \\
\text { draw in investment } \\
\text { from outside Bristol }\end{array}$ & $\begin{array}{l}\text { Attractive, suitable } \\
\text { buildings for } \\
\text { occupants; } \\
\text { infrastructure that } \\
\text { enables open data, } \\
\text { convenient travel, } \\
\text { etc. }\end{array}$ \\
\hline $\begin{array}{l}\text { Stakeholding } \\
\text { needs } \\
\text { (situation } \\
\text { oriented) - } \\
\text { what's at } \\
\text { stake }\end{array}$ & $\begin{array}{c}\text { Need to } \\
\text { demonstrate to } \\
\text { developers that } \\
\text { additional costs for } \\
\text { low-carbon are not } \\
\text { excessive and are } \\
\text { offset by } \\
\text { attractiveness of the } \\
\text { TQEZ }\end{array}$ & $\begin{array}{l}\text { Need to produce an } \\
\text { energy master plan } \\
\text { that is "realistic" and } \\
\text { will be adopted by } \\
\text { implementers }\end{array}$ & $\begin{array}{l}\text { Need to get clear on } \\
\text { metrics and } \\
\text { terminology - } \\
\text { BREEAM Excellent } \\
\text { is not necessarily } \\
\text { low carbon }\end{array}$ & $\begin{array}{c}\text { Need to get } \\
\text { investors and land } \\
\text { owners to commit to } \\
\text { financial backing of } \\
\text { the development of } \\
\text { different plots within } \\
\text { the TQEZ }\end{array}$ & $\begin{array}{c}\text { Need that the TQEZ } \\
\text { development } \\
\text { doesn't add to } \\
\text { existing traffic } \\
\text { congestion } \\
\text { problems }\end{array}$ \\
\hline $\begin{array}{l}\text { Stakeholding } \\
\text { needs } \\
\text { (system } \\
\text { oriented) - } \\
\text { stakeholding } \\
\text { development }\end{array}$ & $\begin{array}{l}\text { BCC need to strike } \\
\text { a balance between } \\
\text { the needs of } \\
\text { economic and low- } \\
\text { carbon } \\
\text { development, } \\
\text { avoiding a race to } \\
\text { the bottom with } \\
\text { other cities and } \\
\text { instead raising } \\
\text { standards }\end{array}$ & $\begin{array}{c}\text { A planning } \\
\text { document only } \\
\text { works when it is a } \\
\text { living one and } \\
\text { developers accept } \\
\text { it, but stakeholder } \\
\text { engagement with } \\
\text { energy master } \\
\text { planning has been } \\
\text { low so far }\end{array}$ & $\begin{array}{l}\text { Must deliver the } \\
\text { best projects for the } \\
\text { money available } \\
\text { while meeting the } \\
\text { spatial framework } \\
\text { goals; the "green" } \\
\text { business case } \\
\text { needs to be proven } \\
\text { by all orgs involved }\end{array}$ & $\begin{array}{l}\text { The TQEZ's } \\
\text { purpose is } \\
\text { economic } \\
\text { development, } \\
\text { placemaking, not } \\
\text { building a low- } \\
\text { carbon district; low- } \\
\text { carbon } \\
\text { requirements } \\
\text { mustn't impede the } \\
\text { purpose }\end{array}$ & $\begin{array}{c}\text { Bristol is the } 2015 \\
\text { European Green } \\
\text { Capital; the TQEZ } \\
\text { should be a } \\
\text { showcase for } \\
\text { sustainability as well } \\
\text { as providing growth }\end{array}$ \\
\hline
\end{tabular}

Table 2: Bristol STEEP Stakeholders, Stakes and Stakeholding Needs

\section{Interpretation of the STEEP Results}

This section provides reflections on the project outcomes and is based largely on the outcomes of the Bristol project and the reflective study. Some of the CATWOE terms from SSM are used here, as defined in section3.2.

\subsection{STEEP Methodology Review}

At the beginning of the project, the project team had been aware that the STEEP methodology, as a PSM, was on the edge in terms of applicability and would be hard to make effective. During discussions 
towards the middle and end of the project, there was an acknowledgement that whilst the PSMs included in the STEEP methodology had been applied according to their underlying theory, basic assumptions about the problem context which are embedded in those PSMs - especially regarding the existence of legitimacy for a shared purpose - had not been considered sufficiently before starting the work. The use of a PSM is appropriate only once the process of interessement has happened and there is willingness from those with a stake in the problem to participate in problematisation. Additionally, and paradoxically, the scope of an intervention sometimes only emerges from the process of applying a method within an intervention - despite there being an ongoing or long-term goal.

The STEEP project team initially assumed that the problem owner (in a SSM sense) was the Future Cities team at BCC. They were indeed the problem owners for the sustainability vision (and were the active partners from BCC involved in the project), but they were not the problem solvers - they could not enact their vision directly, and could not control decision making by other groups within the council, such as the economic development and planning departments, or outside of the council. Those with the decision making power for financing and development, such as the LEP and the private developers, held the power not to be controlled; they could always threaten to withdraw that finance if the council required higher standards such as very high levels of energy efficiency in buildings. And as it turned out, there was very limited interest in the sustainability vision from commercial property developers, the business development department of BCC, and land owners - as evidenced by their lack of participation in the project. The end result of the lack of clear problem ownership was that the effectiveness of the PSMs was limited to making the perception of a messy problem marginally "less messy".

The unfolding of this methodological issue is not so surprising considering that there is little track record of applying PSMs at a social level. For example, Lopes found that in multi-agency situations where there is a lack of authority with regard to the problem PSMs provide limited results in 'promoting mutual accommodations, overcoming individual interests and coping with scarcity of resources at stake' (2015). Franco's case study of the PSM Strategic Choice Approach in a multi organisational team (2009) found that it provided benefits in a situation with high behavioural complexity (implying high uncertainty about guiding values and related agendas between the groups involved) and low structural complexity $^{12}$. The STEEP problem context, however, had both high levels of behavioural complexity (key players were not in a formal agreement with each other in a multi-organisational team) and high levels of structural complexity (the need to consider planning, finance, technology metrics, supply and demand of energy, etc.).

\footnotetext{
${ }^{12}$ We have used the word "complexity" in this article to indicate that a system is both complicated (is comprised of many interconnected elements) and has emergent properties which make managing it difficult.
} 
On a more positive note, the STEEP project showed that once understanding of the problem situation had been improved, applying an interpretivist methodology that can deal with real-world physical and logistical complexity, such as Hierarchical Process Modelling, is a valid approach for supporting the creation of an energy master energy plan. This is exemplified by the fact that the model building process was more straightforward in San Sebastián where there is more control available to the planners - i.e. the situation looks a little more like the multi organisational team that Franco (2009) describes. Additionally, in Bristol the project has given support to the local council in their future implementation of their sustainability vision by providing a model of the decision making architecture. Finally, there was a revealing of inherent complexity through a finding that the processes of enrolling stakeholders and defining scope of transformations are co-dependent and together form a complex problem in their own right (Yearworth 2015).

\subsection{Interpretation of the Reflective Study}

Results from the reflective study provide indications about why there was a lack of interessement from stakeholders and why problematisation was so difficult. Firstly, however, we have to state the situation in which boundary critique was applied was not a perfect fit. In CSH theory, as described in (Ulrich \& Reynolds 2010) and exemplified in several case studies (e.g. (Córdoba \& Midgley 2006), (Donaires 2006)), the method is suitable for exploring and improving emancipatory issues related to planned social interventions. There is an assumption that the planners, including experts and decision makers, have the agency to act, and that there is a danger that those who will be affected by the intervention, including beneficiaries and witnesses (those indirectly affected) will not have enough voice - the emancipatory aspect. In the case of redevelopment of a city zone in a market driven economy, the power of decision making is much more distributed; it is not completely clear who are the decision makers, experts, beneficiaries and witnesses. The boundary critique did shed light on differences in motivation, control, knowledge and legitimacy between the five groups identified. Additionally, the process of carrying out the method forced the project team to explicitly consider the full range of stakeholders related to the project rather than just those who were voluntarily involved or who were clearly identified as key participants.

\subsection{Problematisation and Interessement Revisited}

Regarding problematisation, as noted by (Kawalek et al. 2003), the motivation to change arises from stakeholder perception of there being a problem, and this requires stakeholders to have knowledge about the problem and assign it at least some legitimacy. An absence of motivation was observed for some of the stakeholder groups in STEEP that have the most control over the redevelopment of the TQEZ, along with a perception that the low-carbon target is not really a problem for them. Indeed, since there are few strong reputational, financial or legislative imperatives in the UK for investment and development to 
be very low-carbon, it could be said that they are right to not see this as their problem - in other words, this is largely a structural problem at the societal level.

Regarding interessement, if part of the process is gaining buy-in from relevant actors (White 2009) we can ask what could instigate that interest from the actors involved in the TQEZ redevelopment. It is rather obvious for the principle proponents of the vision, the Future Cities team at BCC, since they have responsibility in enacting the city's long-term goal for carbon emissions reductions. There were also several STEEP participants that had interest because of their knowledge about the issue and understanding of its importance, such as local academics and people from voluntary organisations. Yet in general, those with the highest levels of commitment and interest in the vision had low levels of direct control in enacting it. Conversely, amongst the actors with the most agency to act there appeared to be a broad lack of legitimacy about the issue. The observed general mismatch between power and interest with regard to the low-carbon vision implies that understanding and working with stakeholder motivation is key.

\section{Discussion}

This section discusses the results from the STEEP project presented in Section 5 along with the perspectives on climate change mitigation presented in Section 2. We draw out three key themes from the research that are prominent in exhibiting a need for more methodology development, in order to move towards real-world improvement. Perspectives from the field of Critical Systems Thinking are brought in to shed a new light on the themes. Suggestions for new approaches to the three themes are provided, along with possible research paths forward.

\subsection{Need for New Competencies}

Cities are facing a growing suite of presses from many sides, some of which, such as climate change mitigation and economic growth, exhibit tensions rather than synergies (Heynen et al. 2006), (Jonas et al. 2011). As evidenced by the insufficient rate of transition towards sustainable cities, it appears that decision makers at all levels of society - from leadership, to management, to citizens - need to develop new competencies to deal with new types of problems and overcome barriers to transition. To shed new light on this we bring in the field of Critical Systems Thinking (CST), which is a meta-framework for systems methodologies ${ }^{13}$. CST enables the examination of issues such as temporal scales, spatial scales, problem ownership, and ethics with regards to systems methodologies ((Midgley 1996), (Flood \&

\footnotetext{
${ }^{13}$ In this paper we define systems methodologies as methodologies that are based, at least in some part, on systems concepts (Ackoff 1971) such as interdependency, purpose, boundaries, and emergence.
} 
Jackson 1991)) $)^{14}$. Midgely (1996) identifies several issues in CST related to the general theme of sustainability (which includes low-carbon transition), including: (i) CST is committed to human emancipation, which is usually interpreted as human well-being separate from environmental wellbeing; (ii) there is a lack of clarity on what is considered to be human "progress", with progress for some possibly being setbacks for others; and (iii) CST's commitment to critical awareness is not supported by a method for such awareness - although CSH comes close. Midgely states that a critique is needed in society regarding the process of creating vision and ideas of improvement - there needs to be an effective process of problematisation that asks "progress for whom?" He recommends use of an "alternative pluralist theory" that does not assume that humans have an inherent interest in predicting and controlling the natural world.

The lack of problematisation of progress was seen in the Bristol STEEP project. The designation of the TQEZ as an enterprise zone by central government prioritised economic growth since the goals of the redevelopment are to provide jobs and income for the city. The local council published a vision for how the redevelopment could also be sustainable (or at least more sustainable than a business as usual case), but the sustainability vision has always to compete with the reality of attracting investment and costbenefit accounting. In fact, the redevelopment as a whole will increase Bristol's greenhouse gas emissions. It includes the building of a large performance arena which, as some participants in the STEEP workshops noted, will increase emissions through increased travel and energy used to run the arena. An open competition for citizens to choose an arena design led to the selection of the most attractive one rather than the design that was most environmentally friendly. The final spatial framework (Bristol City Council City Design Place Directorate 2016) requires new buildings to achieve BREEAM Excellent, which is ambitious but not the highest level that can be achieved (BREEAM Outstanding). What if there had been a wider questioning of "progress for whom?" that considered the impacts of decisions made at build time on stakeholders not considered, such as future generations? Perhaps new ways could have been found to overcome the barriers to truly low-carbon development.

This vision of engaging in a criticality of basic assumptions may not be achievable, however, without the development of the kind of citizen competencies envisaged by Ulrich in his discussion of reflective practice in civil society: 'systemic thinking may become the source of a common reflective competence of professionals and citizens' (Ulrich 2000). Competency in systemic thinking, and in working with boundary judgments, could improve the participation of stakeholders in a city's low-carbon vision in several ways. For example, systems thinking competency could provide a structured way for people to

\footnotetext{
${ }^{14}$ Regarding the relationship between PSMs and critical systems thinking, just as PSMs were first developed as a response to the limited applicability of operational research methods to wicked problem situations, CST arose as a critical reflection on PSMs due to the limits of their applicability. CST attempts to break out of those limitations by adopting a meta-methodology stance that transcends the context/limit problem.
} 
rethink difficult issues of accountability for externalities and responsibility for local and global issues. Climate change is a classic tragedy of the commons problem (Garrity 2012). The global climate is a "commons" and cities can be "free riders" with regard to climate change mitigation. Systems concepts such as boundaries, feedback loops and emergence bring a different perspective from the one provided by economics.

Historically, local authorities have not driven the level of change in society that would be required to achieve a low-carbon city, which would require working with many actors and organisations, spanning many different scales, and developing multi-level governance approaches (Hodson \& Marvin 2010). Elzen et al. (2004) find that such transitions cannot be directed by governments but only governed, with public authorities providing 'directionality and coordination at the systems level'. Systems thinking competency, including the use of PSMs in which scope and stakeholding is determined dynamically through an iterative, systemic process, could be a key skill for local governments to support an intentional shift from directionality to adaptive governance on climate mitigation. Boundary critique would provide a means to understand issues of motivation, control, knowledge, and legitimacy for the stakeholder groups in the city that need to be engaged in delivering the vision - leading to more appropriate forms of governance that are responsive to a wide plurality of stakeholders' stakes and stakeholding needs.

Another competency is the incorporation of complexity concerns into planning through simulation modelling. For example, Khan and Pinter (2016) created a visual tool for exploring the relationship between urban form, energy efficiency and carbon emissions. Combining quantitative systemic analysis methods to deal with complexity, and qualitative people-focused systems approaches such as PSMs, would provide a set of competencies that will enable much more effective decision making and stakeholder engagement.

\subsection{Dealing with Wickedness}

While identifying climate change mitigation as a wicked problem is a good first step, successfully dealing with wickedness in real world situations is, as the name suggests, very difficult. Conklin (2005) describes ways that decision makers commonly try to cope with a wicked problem, which include: (i) not questioning the assumed definition of the problem, (ii) claiming that the problem has already been solved, (iii) focusing on a selected group of targets and measurements of success while ignoring others, (iv) describing the problem as being just like another problem that has been solved. These approaches usually fail in the long run and then the wicked problem "reasserts itself, perhaps in a different guise, as if nothing had been done" (ibid.) - or it may even have been made worse.

Signs of wickedness were seen in the STEEP project as follows (the following characteristics of a wicked problem are taken from (Peterson 2009)): (i) 'No definitive formulation of the problem exists.' In other words, there is difficulty in establishing a restricted set of possible solutions and in defining 
measures of performance (Rittel \& Webber 1973). In STEEP the council could not set concrete performance metrics for the TQEZ as they do not have power to require a carbon performance metric or measure it in privately owned infrastructure or transportation. Furthermore, while the energy master plan identified several directly implementable solutions for the council, such as district heating, most user-related solutions were out of the realm of the council. (ii) 'Its solution is not true or false, but rather better or worse.' The choice of "low-carbon" as an aspiration for STEEP was a compromise arrived at by the project team after deciding that the original one of "zero energy" would be unpalatable to most of the stakeholders involved in the development and impossible to achieve. But low carbon is only a better option than development without consideration of greenhouse gas emissions. It is likely that emissions will still rise. (iii) 'Stakeholders have radically different frames of reference concerning the problem.' As evidenced from the reflective study results, the main stakeholder groups had a range of different stakes and stakeholdings in relation to the redevelopment of the TQEZ. This meant that although the STEEP methodology was designed to co-create accommodations between stakeholders towards the sustainability goal through processes such as group model building, it proved difficult to achieve in part due to a reluctance to participate by those with the most power to enact the vision; (iv) 'Constraints and resources for solution change over time.' Whether there is investment money, and which companies and public bodies are willing to support development or move into the TQEZ will depend on many factors. Inter-urban competition for investment means a very strong sustainability requirement could risk losing investment. (v) 'The problem is never solved.' Economic growth will always increase environmental impacts. By how much and in what ways may vary, but the problem of balancing economy and environment is unlikely to be solved.

Several approaches have been proposed to improve the poor track record of dealing with wickedness. In terms of problem understanding, the problem can be broken down into more manageable, "tame" components through identifying the multiple factors and forces that make up the problem. The problem space for climate change mitigation at the city scale is multi-layered and pluralistic. Integrating a wide body of knowledge from different disciplines could help to support action within the problem context. One possible method is Integrated Assessment, which is a comprehensive, systematic approach to integrating knowledge from various disciplines and stakeholder groups which enables the consideration of the needs and concerns of organisations, communities, and the environment (Hutchinson et al. 2006). For example, it has been used to carry out a comprehensive assessment of the impact of climate change on urban areas, enabling urban planning researchers to 're-frame the questions that are asked so as to link global, regional and local scales and their interactions in the context of future urban planning' (Dawson et al. 2014).

This approach could help to identify smaller, more "tame" problems that fit with the dominant ecological modernisation ideology and can be addressed with standard policies, engineering methods, and systems methods suited to less pluralist problem contexts such as Systems Engineering (Sheard \& 
Mostashari 2009). Additionally, it could act as evidence to support decision making and help make clear the relevance of the problem for different stakeholders, in terms of what it means for them supporting PSMs such as hierarchical process modelling and action planning. One of the steps in an integrated assessment is establishing measures of system performance. As seen in STEEP, failing to clearly establish these problem basics can reduce the legitimacy of the vision and make problematisation more difficult. An integrated assessment done before STEEP started could have reviewed the issue of what is involved in being a low-carbon city - does that mean reducing building-based emissions, transport-based emissions, and/or embodied carbon in products and services, and by how much, and how does that relate to economic activity?

In terms of solutions, an approach that incorporates several competencies can be effective. For example, Kreuter et al. (2004) found that improvement in environmental health issues would be more likely to be achieved using an approach that includes systems thinking, community education, robust application of science, and stakeholder engagement. Similarly, Head and Alford (2008) state that whilst collaboration is important in tackling wicked problems, it needs to be combined with systems thinking and adaptive leadership. A multi-methodology approach that incorporates leadership, PSMs, information and community involvement could be more likely to succeed than separate efforts. STEEP brought PSMs into this realm and found that they can improve the problem space. Combining the results of STEEP with complementary approaches such as collaborative governance and voluntary agreements could prove to be more effective, especially when combined with the sustainability leadership that is already being seen in many cities.

\subsection{Behavioural Complexity: Discordant Reference Systems}

Climate change is by nature a global and long-term problem. Anyone wishing to understand the problem and its wider implications must adopt a reference system with a very wide boundary. Climate scientists studying the earth's natural systems do this as part of their work but it not necessary for individuals working in business or some parts of government. Thus, one of the uncertainties in whether it is possible to have meaningful discourse between those stakeholders who are important to the problem is whether or not climate change is included within their reference systems. That many business leaders lobby against legislation that would change greenhouse gas emissions from a business externality to a responsibility can be understood, since their responsibility is primarily towards their own organisation. However, when this is done by everyone it makes transformative progress on sustainability issues almost impossible.

The theory of "discordant pluralism", as discussed by Gregory ((1996b), (1996a)) provides a new perspective. Discordant pluralism has three main features or foundational assumptions: (i) 'decisions are local, contingent, and historically situated in nature; (ii) communication between radically different and alien perspectives is promoted; (iii) insights gained through such communication provide for 
ethical decision making since oppositional views are juxtaposed within a constellation that supports both one perspective and the other' (Flood \& Romm 1996). These three foundational assumptions promote new forms of communication to support ethical decision making. Within them there is an acknowledgement that oppositional views, with different perspectives, exist; however, these views are seen as supplementing one another rather than competing with one another. Discordant pluralism accepts that some paradigms or value systems that are so antagonistic that there is no position from which they can be reconciled - but, in theory, when viewed as a constellation (Gregory 1996b) numerous perspectives can be supported at the same time.

The reflective study in STEEP revealed that those with the highest levels of commitment and interest in the vision had low levels of direct control in enacting it, while those with the most agency to act showed a broad lack of legitimacy towards the issue. We do not have data on the value systems of the stakeholders involved, but the observed general mismatch between power and interest with regard to the low-carbon vision indicates a discordance between them about the issue, with no obvious path towards or expectation of alignment in future. For now, the dominant value system in the UK is towards business as usual, with ecological modernisation seen as the solution to sustainability issues, even though, as noted by Kallis (2009) and While (2004), more radical approaches are likely to be needed to achieve the change that science says is required. The discord between those supporting business as usual and those asking for radical change remains in place for now. However, discordant pluralism theory implies that achieving accommodation between stakeholders is not necessary to bring about some form of improvement, meaning that the mismatch between power and interest may not be an impossible barrier.

Could discordant pluralistic theory lead to practical ways of improving communication between stakeholders about the climate issue? No formal methodology exists at present. Jackson (2007) describes discordant pluralism as being a multi-methodology within which paradigms are managed by mediating between them, allowing critique between paradigms rather than from some place above. Gregory (1996a) proposes that the recognition of differences and otherness, coupled with critical systems thinking, could help to answer ethical questions about the legitimacy of different perspectives. However, interessement is still required to make progress since stakeholders must participate in a process of critical appreciation, and 'it remains to be seen whether fundamentalists can indeed be sufficiently motivated to abandon their "closed” positions and enter into open discourse' (Gregory 1996a).

The challenge for bringing in acknowledgment of discordance into low-carbon urban development will be in developing new forms of engagement. Ideally such engagement would draw in all the key actors to participate in an open discourse and that discourse would be done in the spirit of a critique between paradigms - a constellation (Gregory 1996a). And in line with the perspective of discordant pluralism, it would need to be 'local, contingent, and historically situated in nature' (Flood \& Romm 1996). We 
can see signs of this in the way that the STEEP methodology was carried out in the three participating cities. The project in each city set different goals (yet related to the general theme of the project), had slightly different experience of stakeholder engagement, and gained slightly different benefits from the application of the methodology.

What might a new form of engagement achieve? Within a city, it might ideally achieve the widespread recognition within public and private sectors that climate change mitigation is a problem that is relevant for them - i.e. creating stakeholder interessement in the problem and a willingness to participate in problematisation. This would form a good foundation for the use of formal and ad-hoc PSMs in planning and evaluating action, and help to avoid similar issues to those found within the STEEP implementation. To successfully develop this type of engagement would require new research that develops and tests theory and methodology. This research could build upon the new understandings developed through STEEP and would be timely in terms of the issues currently being faced by cities across the world.

The city of Bristol's colourful terraced houses provides a concluding and positive metaphor. The houses are a well-recognised feature of the city, providing local character and featuring in many of the city's publications. Houses are painted in bright colours, with each house colour different to its neighbour. This creates a constellation of "discordant" colours whose overall effect provides a common good of enjoyment for both citizens and visitors.

\section{Conclusions}

Many cities around the world have set climate change mitigation targets, yet actions to implement these targets have proved so far to be inadequate in their effectiveness. There can be a lack of clarity about who is responsible to act, how to engage with a wide range of stakeholders, how to set goals, and how to measure success. Climate change mitigation is seen largely as an issue of ecological modernisation, a matter of technological improvement which is feasible although requiring a good deal of intersectoral collaboration. However, it has also been described as a wicked problem, an issue that will require ecostate restructuring and a new urban political ecology. Barriers to transformation are complex and multilayered.

Problem structuring methods (PSMs) are a way of working with problem situations in which there are high levels of behavioural and structural complexity. These methods bring structure and theory to the difficult job of bringing about improvements in organisations and multi organisational collaborations. Most PSMs were developed in situations in which an interest in improving the problem situation already exists and so they facilitate problematisation and achieving accommodations between stakeholders. Within a multi-organisational collaboration the effectiveness of PSMs is weaker and facilitation is particularly challenging. PSMs appear at first look to have potential to improve climate change mitigation actions in cities, but interest from key stakeholders may not exist at the city scale and facilitation will be even more difficult than in a multi-organisational collaboration . 
The STEEP project applied a PSM methodology to support the development of an energy master plan for three city districts that were being redeveloped in Bristol (UK), San Sebastián (Spain) and Florence (Italy). These redevelopments had the dual goals of economic development and being sustainable in some way. The STEEP methodology proved to be effective in reducing the wickedness of the problem and providing the local authority with a much clearer path forward towards setting and reaching realistic goals. In the Bristol project, a model of the decision making structure was developed to support future decision making, a subject that had previously not been acknowledged or understood. The STEEP project did not go entirely as planned, with issues of a lack of clarity on problem ownership and lack of interessement. A reflective study using the boundary critique method provided insights into the lack of stakeholder interessement finding that the levels of motivation, control, knowledge, and legitimacy towards the low-carbon vision differed for each of the key stakeholder groups, with a general mismatch between having power and interest towards the low-carbon vision across the groups.

The results from STEEP were reviewed along with relevant ideological perspectives and governance mechanisms form the literature, and informed by concepts from the field of critical systems thinking. Three key issues were examined: (i) the need for new competencies, (ii) dealing with wickedness, and (iii) behavioural complexity and discordant reference systems. The discussion proposes how each of these issues might be improved through the application of additional non-PSM theories and methods, to support the use of PSMs. For example, Integrated Assessment would be suitable as preparation for applying PSMs where there is a large amount of structural and behavioural complexity. Discordant pluralism, which is not a method but a conceptual approach, could be used to make progress in situations in which there is a lack of interessement from stakeholders, and accommodations between stakeholders are unlikely to be achieved. New competencies could enable decision makers across society to better understand the nature of the problem and find more appropriate solutions.

Since cities around the world are facing an increasing set of competing pressures, including the need to reduce their ecological footprint, we propose that research into new methodology and theory development are needed in response. A valuable part of this research would be to develop new types of stakeholder engagement that enable progress to be made in situations where participation in problematisation by key stakeholders is difficult or not possible. This research could build upon the new understandings developed through STEEP and would be timely in terms of the COP21 Paris agreement.

\section{Acknowledgements}

This work was supported in part by the EU FP7-ENERGY-SMARTCITIES-2012 (314277) project STEEP (Systems Thinking for Comprehensive City Efficient Energy Planning). The authors would like to sincerely thank the other members of the STEEP project teams in Bristol, San Sebastián and Florence; 
our consulting organisation partners; and all of the attendees at the numerous model building workshops that took place throughout the project.

\section{References}

Ackermann, F., 2012. Problem structuring methods "in the Dock": Arguing the case for Soft OR. European Journal of Operational Research, 219(3), pp.652-658.

Ackoff, R., 1971. Towards a System of Systems Concepts. Management Science, 17(11), pp.661-672.

Alusi, A. et al., 2011. Sustainable Cities: Oxymoron or the Shape of the Future?, Harvard Business School Organizational Behavior Unit Working Papers; Volume 11, Issue 62, Edition 3.

Andersen, D. et al., 2007. Group Model Building: Problem Structuring, Policy Simulation and Decision Support. Journal of the Operational Research Society, 58(5), pp.691-694.

Andersen, D. \& Richardson, G., 1997. Scripts for group model building. System Dynamics Review, 13(2), pp.107-129.

Anderson, K., 2015. Talks in the city of light generate more heat. Nature, 528, p.437.

Ansell, C. \& Gash, A., 2008. Collaborative governance in theory and practice. Journal of Public Administration Research and Theory, 18(4), pp.543-571.

Attwater, R., 2000. Pluralism, Economic Rhetoric, and Common Property. Systemic Practice and Action Research, 13(4), pp.543-557.

Australian Public Service Commission, 2007. Tackling Wicked Problems, a Public Policy Perspective, Commonwealth of Australia: Routledge.

Bailey, I., Gouldson, A. \& Newell, P., 2011. Ecological Modernisation and the Governance of Carbon: A Critical Analysis. Antipode, 43(3), pp.682-703.

Bell, S. \& Morse, S., 2007. Problem structuring methods: theorizing the benefits of deconstructing sustainable development projects. Journal of the Operational Research Society, 58, pp.576-587.

Berger, G. et al., 2001. Ecological Modernization as a Basis for Environmental Policy: Current Environmental Discourse and Policy and the Implications on Environmental Supply Chain Management. Innovation: The European Journal of Social Science Research, 14(1), pp.55-72.

Bristol City Council, 2012a. Bristol Central Area Action Plan and City Centre Public Realm and Movement Framework: Responses to Consultation, August 2012,

Bristol City Council, 2012b. Bristol Development Framework Central Area Action Plan, Options Consultation, February 2012,

Bristol City Council, 2013. Temple Quarter Enterprise Zone: A Sustainable Urban Quarter by Design, City Design Group, Planning and Sustainable Development Division, Neighbourhoods and City Development.

Bristol City Council, 2012c. Temple Quater Enterprise Zone. Shaping Quality Places: Spatial Framework Preview, City Design Group, Planning and Sustainable Development. Available at: www.bristoltemplequarter.com/assets/articles/Spatial framework preview.pdf.

Bristol City Council City Design Place Directorate, 2016. Bristol Temple Quarter Enterprise Zone Spatial Framework; The Framework, Bristol. Available at: www.bristoltemplequarter.com/spatialframework.

Brown, A.J., 2002. Collaborative governance versus constitutional politics: Decision rules for sustainability from Australia's South East Queensland forest agreement. Environmental Science and Policy, 5(1), pp.19-32. 
Callon, M., 1986. Some elements of a sociology of translation: Domestication of the scallops and the fishermen of St Brieuc Bay. Power, action and belief. In J. Law, ed. A New Sociology of Knowledge?. London: Routledge, pp. 196-229.

Checkland, P., 1981. Systems Thinking, Systems Practice, Wiley, Chichester.

Checkland, P., 2000. The emergent properties of SSM in use: A symposium by reflective practitioners. Systemic Practice and Action Research, 13(6), pp.799-823.

Checkland, P. \& Holwell, S., 2004. "Classical" OR and "soft" OR - an asymmetric complementarity. In M. ed. Pidd, ed. Systems modeling: theory and practice. Wiley, UK, pp. 45-60.

Checkland, P. \& Scholes, J., 1999. Soft Systems Methodology: a 30-Year Retrospective, Chichester: John Wiley and Sons Ltd.

Checkland, P. \& Scholes, J., 1990. Soft systems methodology in action, Chichester: John Wiley and Sons Ltd.

Coelho, D., Antunes, C.H. \& Martins, A.G., 2010. Using SSM for structuring decision support in urban energy planning. Technological and Economic Development of Economy, 16(4), pp.641-653.

Conklin, J., 2005. Wicked Problems and Social Complexity. In Dialogue Mapping: Building Shared Understanding of Wicked Problems. Wiley.

Córdoba, J.R. \& Midgley, G., 2006. Broadening the Boundaries: An Application of Critical Systems Thinking to IS Planning in Colombia. Journal of the Operational Research Society, 57(9), pp.1064-1080.

Couch, C. \& Dennemann, A., 2000. Urban regeneration and sustainable development in Britain: The example of the Liverpool Ropewalks Partnership. Cities, 17(2), pp.137-147.

Dawson, R. et al., 2014. Understanding cities: Advances in integrated assessment of urban sustainability, Final Report of COST Action TU0902, Centre for Earth Systems Engineering Research (CESER), Newcastle, UK.

Dixon, T., 2006. Integrating Sustainability into Brownfield Regeneration: Rhetoric or Reality? - An Analysis of the UK Development Industry. Journal of Property Research, 23(3), pp.237-267.

Dixon, T., 2007. The Property Development Industry and Sustainable Urban Brownfield Regeneration in England: An Analysis of Case Studies in Thames Gateway and Greater Manchester. Urban Studies, 44(12), pp.2379-2400.

Donaires, O.S., 2006. A Critical Heuristic Approach to the Establishment of a Software Development Process. Systemic Practice and Action Research, 19(5), pp.415-428.

Edenhofer, O. et al., 2014. Summary for Policymakers. In Climate Change 2014, Mitigation of Climate Change. Contribution of Working Group III to the Fifth Assessment Report of the Intergovernmental Panel on Climate Change. Cambridge, United Kingdom and New York, NY, USA.: Cambridge University Press.

Elzen, B., Geels, F. \& Green, K., 2004. General Introduction: System Innovation and Transitions to Sustainability. In B. Elzen, F. Geels, \& K. Green, eds. System Innovation and Transition to Sustainability: Theory, Evidence and Policy. Cheltenahm, UK: Edward Elgar Publishing Ltd.

Flood, R. \& Jackson, M.C., 1991. Critical Systems Thinking: Directed Readings, New York: John Wiley and Sons.

Flood, R. \& Romm, N., 1996. Diversity Management; Theory in Action (p86). In R. Flood \& N. Romm, eds. Critical Systems Thinking: Current Research and Practice. London: Springer.

Flynn, A. et al., 2016. Eco-cities, governance and sustainable lifestyles: The case of the Sino-Singapore Tianjin Eco-City. Habitat International, 53, pp.78-86. 
Forrester, J., 1991. System Dynamics and the lessons of 35 years. In K. B. DE GREENE, ed. The Systemic Basis of Policy Making. MIT Press, Cambridge MA.

Foxon, T.J. \& Pearson, P., 2008. Overcoming barriers to innovation and diffusion of cleaner technologies: some features of a sustainable innovation policy regime. Journal of Cleaner Production, 16(1), pp.S148-S161.

Franco, L.A., 2008. Facilitating collaboration with problem structuring methods: A case study of an inter-organisational construction partnership. Group Decision and Negotiation, 17(4), pp.267286.

Franco, L.A., 2009. Problem structuring methods as intervention tools: Reflections from their use with multi-organisational teams. Omega, 37(1), pp.193-203.

Friend, J. \& Hickling, A., 1997. Planning Under Pressure: The Strategic Choice Approach 2nd ed., Butterworth- Heinemann: Oxford.

Garrity, E.J., 2012. Tragedy of the Commons, Business Growth and the Fundamental Sustainability Problem. Sustainability, 4(12), pp.2443-2471.

Gollagher, M. \& Hartz-Karp, J., 2013. The role of deliberative collaborative governance in achieving sustainable cities. Sustainability (Switzerland), 5(6), pp.2343-2366.

Gregory, A.J. et al., 2013. A problem structuring method for ecosystem-based management: The DPSIR modelling process. European Journal of Operational Research, 227(3), pp.558-569.

Gregory, W.J., 1996a. Dealing with Diversity. In R. Flood \& N. Romm, eds. Critical Systems Thinking: Current Research and Practice. London: Springer.

Gregory, W.J., 1996b. Discordant pluralism: A new strategy for critical systems thinking. Systems Practice, 9(6), pp.605-625.

Hall, J.W., Blockley, D.I. \& Davis, J.P., 1998. Uncertain inference using interval probability theory. International Journal of Approximate Reasoning, 19(3-4), pp.247-264.

Head, B. \& Alford, J., 2008. Wicked Problems: The Implications for Public Management. In International Research Society for Public Management, 12th Annual Conference. Brisbane.

Hector, D., Christensen, C. \& Petrie, J., 2009. A problem-structuring method for complex societal decisions: Its philosophical and psychological dimensions. European Journal of Operational Research, 193(3), pp.693-708.

Heynen, N.C., Kaika, M. \& Swyngedouw, E., 2006. In the Nature of Cities: Urban Political Ecology and the Politics of Urban Metabolism, Taylor \& Francis.

Hodson, M. \& Marvin, S., 2010. Can cities shape socio-technical transitions and how would we know if they were? Research Policy, 39(4), pp.477-485.

Holland, J.H., 1992. Adaptation in Natural and Artificial Systems: An Introductory Analysis with Applications to Biology, Control, and Artificial Intelligence, MIT Press, Cambridge, Mass.

Hutchinson, M.F. et al., 2006. Integrated Assessment of Climate Change Impacts. In Report on Methodology and Workshop held at the ANU 3-4 July 2005. Australian National University.

Huxham, C., 1991. Facilitating Collaboration: Issues in Multi-organizational Group Decision Support in Voluntary, Informal Collaborative Settings. Journal of the Operational Research Society, 42(12), pp.1037-1045.

Jackson, M.C., 2006. Creative Holism: A Critical Systems Approach to Complex Problem Situations. Systems Research and Behavioral Science, 23, pp.647-657.

Jackson, M.C., 2007. Systems approaches to management, New York: Kluwer Academic/Plenum.

Jackson, M.C., 2003. Systems thinking: creative holism for managers, Wiley. 
Jonas, A.E.G., Gibbs, D. \& While, A., 2011. The New Urban Politics as a Politics of Carbon Control. Urban Studies, 48(12), pp.2537-2554.

Kallis, G., Kiparsky, M. \& Norgaard, R., 2009. Collaborative governance and adaptive management: Lessons from California's CALFED Water Program. Environmental Science and Policy, 12(6), pp.631-643.

Kawalek, P., Wastell, D. \& Newman, M., 2003. Problematisation and Obfuscation in E-Government. In R. Traunmüller, ed. Electronic Government; Proceedings of the Second International Conference, EGOV. Prague: Springer, pp. 228-233.

Khan, F. \& Pinter, L., 2016. Scaling indicator and planning plane: An indicator and a visual tool for exploring the relationship between urban form, energy efficiency and carbon emissions. Ecological Indicators, 67, pp.183-192.

Kousky, C. \& Schneider, S.H., 2003. Global climate policy: will cities lead the way? Climate Policy, 3(4), pp.359-372.

Kreuter, M.W. et al., 2004. Understanding wicked problems: a key to advancing environmental health promotion. Health Education \& Behavior, 31(4), pp.441-54.

Lopes, M., Antunes, C.H. \& Martins, N., 2015. Towards more effective behavioural energy policy: An integrative modelling approach to residential energy consumption in Europe. Energy Research \& Social Science, 7, pp.84-98.

Marashi, E. \& Davis, J., 2006. An Argumentation-Based Method for Managing Complex Issues in Design of Infrastructural Systems. Reliability Engineering \& System Safety, 91(12), pp.15351545 .

Marashi, S.E., Davis, J.P. \& Hall, J.W., 2008. Combination methods and conflict handling in evidential theories. International Journal of Uncertainty Fuzziness and Knowledge-Based Systems, 16(3), pp.337-369.

March, H. \& Ribera-Fumaz, R., 2014. Smart contradictions: The politics of making Barcelona a Selfsufficient city. European Urban and Regional Studies, 23(4), pp.816-830.

Maru, Y.T. \& Woodford, K., 2001. Enhancing Emancipatory Systems Methodologies for Sustainable Development. Systemic Practice and Action Research, 14(1), pp.61-77.

Midgley, G., 2003. Science as Systemic Intervention: Some Implications of Systems Thinking and Complexity for the Philosophy of Science. Systemic Practice and Action Research, 16(2), pp.7797.

Midgley, G. et al., 2013. Towards a new framework for evaluating systemic problem structuring methods. European Journal of Operational Research, 229(1), pp.143-154.

Midgley, G., 1996. What is this thing called CST? In Critical Systems Thinking: Current Research and Practice. New York: Plenum Press, pp. 11-24.

Midgley, G., Munlo, I. \& Brown, M., 1998. The Theory and Practice of Boundary Critique: Developing Housing Services for Older People. Journal of the Operational Research Society, 49(5), pp.467478.

Mingers, J., 2011. Soft OR comes of age-but not everywhere! Omega, 39(6), pp.729-741.

Mingers, J. \& Rosenhead, J., 2004. Problem structuring methods in action. European Journal of Operational Research, 152(3), pp.530-554.

Neves, L. et al., 2004. Using SSM to Rethink the Analysis of Energy Efficiency Initiatives. Journal of the Operational Research Society, 55(9), pp.968-975.

Ormerod, R.J., 2013. The mangle of OR practice: towards more informative case studies of "technical" projects. Journal of the Operational Research Society, 65(8), pp.1245-1260. 
Parthan, B. et al., 2010. Lessons for low-carbon energy transition: Experience from the Renewable Energy and Energy Efficiency Partnership (REEEP). Energy for Sustainable Development, 14(2), pp.83-93.

Pellow, D.N., Schnaiberg, A. \& Weinberg, A., 2000. Putting the Ecological Modernisation Thesis to the Test: The Promises and Performances of Urban Recycling. Advanced Industrial Countries, Environmental Politics, 9(1), pp.109-137.

Peterson, H.C., 2009. Transformational supply chains and the "wicked problem" of sustainability: aligning knowledge, innovation, entrepreneurship, and leadership. Journal on Chain and Network Science, 9(2), pp.71-82.

Raupach, M.R. et al., 2007. Global and regional drivers of accelerating CO2 emissions. Proceedings of the National Academy of Sciences of the United States of America, 104(24), pp.10288-10293.

Rees, W.E., 1997. Is "sustainable city” an Oxymoron? Local Environment, 2(3), pp.303-310.

Reynolds, M., 2008. Getting a Grip: Critical Systems for Corporate Responsibility. Systems Research and Behavioral Science, 25, pp.383-395.

Reynolds, M. \& Holwell, S., 2010. Systems Approaches to Managing Change: A Practical Guide M. Reynolds \& S. Holwell, eds., London: Springer London.

Rezessy, S. \& Bertoldi, P., 2011. Voluntary agreements in the field of energy efficiency and emission reduction: Review and analysis of experiences in the European Union. Energy Policy, 39(11), pp.7121-7129.

Rittel, H. \& Webber, M.M., 1973. Dilemmas in a General Theory of Planning. Policy Sciences, 4, pp.155-169.

Sheard, S.A. \& Mostashari, A., 2009. Principles of Complex Systems for Systems Engineering. Systems Engineering, 12(4), pp.295-311.

Shove, E., 2010. Beyond the ABC: climate change policy and theories of social change. Environment and Planning, 42, p.1273 to 1285.

Sorrell, S. et al., 2004. Understanding Barriers to Energy Efficiency. In Reducing Barriers To Energy Efficiency In Public And Private Organisations. SPRU; Research funded in part by THE EUROPEAN COMMISSION in the framework of the Non Nuclear Energy Programme JOULE III, pp. 161-184.

Sovacool, B.K., 2014. What are we doing here? Analyzing fifteen years of energy scholarship and proposing a social science research agenda. Energy Research and Social Science, 1, pp.1-29.

STEEP Project, 2015. D4.2 Open source Smart City methodology, freely available for reuse, Project no. 314277, Systems Thinking for Comprehensive City Efficient Energy Planning, Seventh Framework Programme, Theme Energy.

Sullivan, R., Gouldson, A. \& Webber, P., 2013. Funding low carbon cities: local perspectives on opportunities and risks. Climate Policy, 13(4), pp.514-529.

Taket, A. \& White, L., 2000. Partnership and participation: decision-making in the multiagency setting, Chichester: Wiley.

Ulrich, W., 2003. Beyond Methodology: Critical Systems Thinking as Critically Systemic Discourse. Journal of the Operational Research Society, 54, pp.35-342.

Ulrich, W., 2001. Critically Systemic Discourse: A Discursive Approach to Reflective Practice in ISD (Part 2). JITTA (Journal of Information Technology, Theory and Application), 3(3), pp.85-106.

Ulrich, W., 2000. Reflective Practice in the Civil Society: The contribution of critically systemic thinking. Reflective Practice: International and Multidisciplinary Perspectives, 1(2), pp.247-268. 
Ulrich, W., 1988. Systems Thinking, Systems Practice, and Practical Philosophy: A Program of Research. Systems Practice, 1(2).

Ulrich, W. \& Reynolds, M., 2010. Critical Systems Heuristics. In M. Reynolds \& S. Holwell, eds. Systems Approaches to Managing Change: A Practical Guide. London: Springer London, pp. 243-292.

Vennix, J., 1996. Group model building: Facilitating team learning using system dynamics, J. Wiley (Chichester and New York).

Weber, L., 1997. Some reflections on barriers to the efficient use of energy. Energy Policy, 25(10), pp.833-835.

While, A., Jonas, A.E.G. \& Gibbs, D., 2010. From sustainable development to carbon control: eco-state restructuring and the politics of urban and regional development. Transactions of the Institute of British Geographers, 35(1), pp.76-93.

While, A., Jonas, A.E.G. \& Gibbs, D., 2004. The Environment and the Entrepreneurial City: Searching for the Urban 'Sustainability Fix' in Manchester and Leeds. International Journal of Urban and Regional Research, 28(3), pp.549-569.

White, L., 2009. Understanding problem structuring methods interventions. European Journal of Operational Research, 199(3), pp.823-833.

White, L. \& Lee, G.J., 2009. Operational research and sustainable development: Tackling the social dimension. European Journal of Operational Research, 193(3), pp.683-692.

Yearworth, M., 2014. D2.5 Evaluation, STEEP PROJECT (314277) - Systems Thinking for Comprehensive City Efficient Energy Planning, University of Bristol; EU Seventh Framework Programme, Theme Energy.

Yearworth, M., 2015. D4.1 Study on the applicability of scaling district interventions to the city level, Project no. 314277, Systems Thinking for Comprehensive City Efficient Energy Planning, Seventh Framework Programme, Theme Energy.

Yearworth, M. et al., 2015. STEEP Project Deliverable D2.1 Energy Master Plan Process Modelling, Project no. 314277. STEEP PROJECT Systems Thinking for Comprehensive City Efficient Energy Planning. Seventh Framework Programme, Theme Energy.

Yearworth, M. \& White, L., 2014. The Non-Codified Use of Problem Structuring Methods and the Need for a Generic Constitutive Definition. European Journal of Operational Research, 237, pp.932-945. 